$9-15-2021$

\title{
Workplace Transformation And Its Tax Compliance Implications
}

Jay A. Soled

Follow this and additional works at: https://digitalcommons.law.villanova.edu/vlr

Part of the Science and Technology Law Commons, Taxation-Federal Commons, Taxation-State and Local Commons, Taxation-Transnational Commons, and the Tax Law Commons

\section{Recommended Citation}

Jay A. Soled, Workplace Transformation And Its Tax Compliance Implications, 66 Vill. L. Rev. 575 (2021). Available at: https://digitalcommons.law.villanova.edu/vlr/vol66/iss3/3

This Article is brought to you for free and open access by Villanova University Charles Widger School of Law Digital Repository. It has been accepted for inclusion in Villanova Law Review by an authorized editor of Villanova University Charles Widger School of Law Digital Repository. 


\title{
WORKPLACE TRANSFORMATION AND ITS TAX COMPLIANCE IMPLICATIONS
}

\author{
JaY A. SOled*
}

\section{Abstract}

Due to technological advances and the COVID-19 pandemic, taxpayers are increasingly utilizing their homes as a focal point from which to conduct their business affairs. On the one hand, the nation should applaud this workplace transformation insofar as it may enhance job performance and efficiency, reduce product cost and overhead, and improve work-life balance. On the other hand, this transformation process may open the door to rampant tax abuse as taxpayers alone or in collusion with their employers seek to transform home usage into a tax shelter refuge.

This analysis delves directly into the income tax compliance concerns that the workplace transformation engenders. It does so by exposing the nature of the problem, its prevalence, what it might cost the nation annually in terms of lost revenue, and why current safeguards are failing to achieve their sought-after objectives.

The good news is that if Congress proactively takes immediate remedial measures to address this nascent problem, such actions could help foster taxpayer compliance, defend the income tax base, and halt the depletion of the nation's revenue coffers. However, if Congress dallies and is derelict in fulfilling its oversight duties, this problem is poised to go from bad to worse.

* Jay A. Soled is a tax professor in the Rutgers Business School at Rutgers University. He has written and lectured about ways to close the tax gap and has testified before Congress regarding this issue as well. 
INTRODUCTION ............................. 577

I. Background ............................ 580

A. Workplace Evolution...................... 581

B. Evolution of the Deductibility of Home Office Expenses ..... 587

1. Legislative Landscape Prior to the Introduction of the Home Office Deduction..................... 588

2. Code Section 280A: Introduction of the Home Office Deduction .......................... 590

II. Issues Associated with the Tax Deductibility of Home

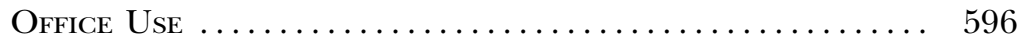

A. Problems Associated with Code Section 280A ........... 596

B. Tax-Avoidance Opportunities Associated with the Workplace

Transformation Trend ....................... 599

1. Traditional Tax-Avoidance Methods ................ 599

2. Novel Tax-Avoidance Methods ................... 600

III. Reform Measures: Existing And Proposed . . . . . . . . . . . . 605

A. Existing Safeguards to Curb Potential Taxpayer Abuse .... . 605

B. Suggested Reform Measures to Curb Potential Taxpayer Abuse ................................... 607

1. Reform the Penalty Structure for Taxpayers ........... 608

2. Address Potential Employer-Employee Collusion ........ . 609

3. Promulgate Regulations to Clarify the Word Regular .... 611

4. Craft a Questionnaire as a Guide for Taxpayers ........ 612

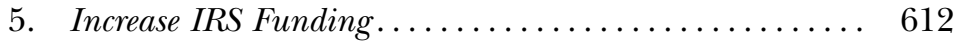

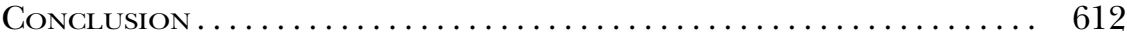

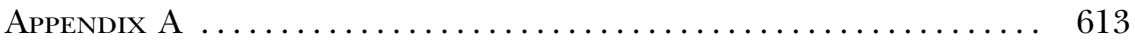




\section{INTRODUCTION}

$\mathrm{D}$ UE to technological advancements and COVID-19, for many taxpayers the workplace has undergone a fundamental transformation. Instead of traveling to and from an office and conducting business from a centralized location, countless taxpayers, particularly in the white-collar sector of the economy, ${ }^{1}$ now fulfill their work-related responsibilities and duties in a decentralized fashion from their homes. ${ }^{2}$ While this workplace transformation has had many significant rippling effects (e.g., drastically reducing the nation's need for commercial office space),${ }^{3}$ one related to income tax compliance stands out: as the traditional work-home dichotomy blurs, it creates opportunities for non-civic-minded taxpayers to masquerade their otherwise nondeductible personal outlays as deductible

1. See Derek Thompson, The Workforce Is About to Change Dramatically, AtLANTiC (Aug. 6, 2020), https://www.theatlantic.com/ideas/archive/2020/08/just-smallshift-remote-work-could-change-everything/614980 [https://perma.cc/L44GJK9B] ("[As a result of the pandemic], tens of millions of American workersmostly in white-collar industries such as tech, finance, and media-were thrust into a sudden, chaotic experiment in working from home . . . For many, the test run is looking more like the long run."). Even in the blue-collar sector, remote work is becoming more popular. See, e.g., Christopher Mims, Remote Work Isn't Just for White-Collar Jobs Anymore, WALL ST. J. (Oct. 22, 2020), https://www.wsj.com/articles/remote-work-isnt-just-for-white-collar-jobs-anymore-11603371826 [https:// perma.cc/7SKL-3FJ3] ("Technology is spreading that lets people do physical work at a distance. ...").

2. See, e.g., Richard Eisenberg, Is Working from Home the Future of Work?, Forbes (Apr. 10, 2020), https://www.forbes.com/sites/nextavenue/2020/04/10/is-working-from-home-the-future-of-work/ [https://perma.cc/S3LN-VBFP] ("One effect of the coronavirus pandemic has been a huge increase in the number of Americans working from home."); Drew Desilver, Before the Coronavirus, Telework Was an Optional Benefit, Mostly for the Affluent Few, Pew Res. CTr. (Mar. 20, 2020), https:// www.pewresearch.org/fact-tank/2020/03/20/before-the-coronavirus-telework-wasan-optional-benefit-mostly-for-the-affluent-few [https://perma.cc/8GA2-XNYT] ("In that respect, COVID-19 may yet do what years of advocacy have failed to: Make telework a benefit available to more than a relative handful of U.S. workers."); Gad Levanon \& Frank Steemers, Working from Home? You're Far from Alone, HiLl (Mar. 29, 2019, 11:00 AM), https://thehill.com/opinion/finance/436317-working-fromhome-youre-not-alone [https://perma.cc/MU2M-V9SP] ("Between 2010 and 2017, 16 percent of all white-collar jobs added to the economy were filled by workers primarily working from home. And that number is conservative because it excludes those who worked part-time, self-employed workers and workers who telecommuted only part of the workweek."); David Streitfeld, White-Collar Companies Race to Be Last to Return to the Office, N.Y. Times (May 8, 2020), https:/ /www.ny times.com/2020/05/08/technology/coronavirus-work-from-home.html [https:// perma.cc/UZ3P-3VVP] ("An increasing number of them, which mostly have whitecollar employees, have recently extended work-from-home policies far beyond the shelter-in-place timelines mandated by state and local authorities.").

3. See, e.g., Peter Bacevice, John Mack, Pantea Tehrani \& Mat Triebner, Reimagining the Urban Office, Harv. Bus. Rev. (Aug. 14, 2020), https://hbr.org/ 2020/08/reimagining-the-urban-office [https://perma.cc/K68T-WXQK] ("The Covid-19 pandemic has abruptly challenged a decade of corporate real estate and workplace design decisions by calling into question the purpose of large centralized office locations."). 
business expenses. ${ }^{4}$ The potential revenue losses stemming from such mischaracterizations are likely to be costly, ${ }^{5}$ and noncompliance of this sort can have a grim corrosive effect upon otherwise compliant taxpayers' willingness to fulfill their civic duties. ${ }^{6}$

Consider the fact that taxpayer noncompliance outlets are multidimensional. The tax gap-the difference between what taxpayers actually pay in taxes in a timely manner and what they should pay if they fully comply with the tax laws ${ }^{7}$-is comprised of several components. ${ }^{8}$ Along with other taxpayer noncompliance vices (e.g., failing to report offshore income),${ }^{9}$ one of the tax gap's central components is taxpayers mischaracterizing their personal consumption as deductible in nature. ${ }^{10} \mathrm{Al}-$

4. The difficulty of distinguishing between business and personal expenses is a commonplace issue. See Douglas P. Krause, The Deductibility of Legal Expenses, 82 Colum. L. Rev. 392, 392 (1982) ("Distinguishing between business and personal expenses in calculating income tax deductions has long been a troublesome process in tax law."); Adi Libson, Taxing Status: Tax Treatment of Mixed Business and Personal Expenses, 17 U. PA. J. Bus. L. 1139, 1139 (2015) ("What is the proper tax treatment of mixed business and personal expenses? This question has much baffled legislators, courts and legal academics.").

5. Revenue losses pertaining to taxpayers mischaracterizing their home expenses as being business in nature are hard to pinpoint with any meaningful exactitude. (This same and costly mischaracterization phenomenon also unfolds in other aspects of daily life such as automobile usage. See generally James Alm \& Jay A. Soled, The Internal Revenue Code and Automobiles: A Case Study of Taxpayer Noncompliance, 14 FLA. TAX REv. 419 (2012) (explaining how taxpayers deduct the personal use of their automobiles, costing the government billions of dollars of lost revenue annually). Nevertheless, the tax gap figures presented in infra notes 8, 9, and 11 help illustrate the magnitude of the noncompliance problem.

6. See Robert H. Frank, Without More Enforcement, Tax Evasion Will Spread Like a Virus, N.Y. Times (Oct. 30, 2020), https://www.nytimes.com/2020/10/30/business/tax-evasion-virus-IRS.html [https://perma.cc/W3HA-8C62] (explaining how tax noncompliance can prove infectious between and among taxpayers, causing even those inclined to be tax compliant to lose their grounding).

7. See generally Robert E. Brown \& Mark J. Mazur, IRS's Comprehensive Approach to Compliance Measurement, 56 NAT'L TAx J. 689 (2003) (setting forth the metrics that help define the tax gap); Mark J. Mazur \& Alan H. Plumley, Understanding the Tax Gap, 60 NAT'L TAx J. 569 (2007) (detailing the elements of taxpayer noncompliance that comprise the tax gap).

8. I.R.S. PuB. 5365 (2019), https://www.irs.gov/pub/irs-pdf/p5365.pdf [https://perma.cc/6S83-K3PT] [hereinafter Publication 5365]. These components, along with their annual costs, are as follows: (i) underreporting (\$352 billion), (ii) underpayment (\$50 billion), and (iii) nonfiling (\$39 billion). Id. Strictly based upon annual revenue losses, the largest of these is underreporting, which the IRS has further broken down by category and cost as follows: (i) individual income tax (\$245 billion), (ii) employment tax (\$69 billion), (iii) corporate income tax ( $\$ 37$ billion), and (iv) estate tax ( $\$ 1$ billion). Id. For a more detailed breakdown of the tax gap, see infra Appendix A.

9. See, e.g., Dave Rifkin, A Primer on the "Tax Gap" and Methodologies for Reducing It, 27 Quinnipiac L. Rev. 375, 391 (2009) (“An estimated \$50-to-\$100 billion (approximately 15 to 30 percent) of the $\$ 345$ billion tax gap is due to offshore tax haven and tax shelter abuses.").

10. Under the Code, the difficulty of distinguishing between business expenditures and personal consumption is long-standing. See, e.g., Daniel I. Halperin, Bus- 
though estimating an exact dollar figure associated with these sorts of taxpayer derelictions is difficult, it is likely to be several billions of dollars annually. ${ }^{11}$

Notwithstanding the gravity of the tax gap problem and its annual cost to the nation's coffers, even in the face of the workplace transformation, the majority of taxpayers are likely to remain tax compliant. ${ }^{12}$ But the workplace transformation process has opened vast new opportunities for less-than-civic-minded taxpayers to reduce their tax burdens. How? By creating a platform for taxpayers to violate one of the fundamental tenets of the Internal Revenue Code (Code) - that is, the prohibition of deductions associated with personal consumption. ${ }^{13}$ Therefore, absent congressional, Treasury Department, and Internal Revenue Service (IRS) vigilance, inattentiveness to this issue is likely to result in the tax gap widening and the deficit growing, both of which will necessitate either

iness Deductions for Personal Living Expenses: A Uniform Approach to an Unsolved Problem, 122 U. PA. L. Rev. 859, 860 (1974) ("The Internal Revenue Service and the courts have struggled to reach a solution as to the deductibility of many kinds of expenditures with very little guidance from Congress."); William A. Klein, The Deductibility of Transportation Expenses of a Combination Business and Pleasure Trip-A Conceptual Analysis, 18 STAN. L. Rev. 1099 (1966) ("In other words, it is not reasonable to expect satisfactory results from simply asking taxpayers, 'Was your combination business and pleasure trip to Florida worth anything to you personally, and if so how much?' Even if a taxpayer could answer that question meaningfully, chances are his answer would be seriously distorted by the conscious or subconscious effect of self-interest.").

11. As previously pointed out, $\$ 245$ billion of the annual tax gap is attributable to taxpayers underreporting their income tax. See Publication 5365, supra note 8. Almost without exception, year in and year out, the most litigated issue involving tax is the legitimacy of trade or business expenses under Code section 162(a). See National Taxpayer Advocate, Most Litigated Issues, in 2019 AnNuAL REPORT TO CONGREss 108, 108, 128 (2020), https://www.taxpayeradvocate.irs.gov/ wp-content/uploads/2020/08/ARC19_Volume1_MostLitigatedIssues.pdf [https:/ /perma.cc/5P3A-XR3U].

12. See James Alm \& Jay A. Soled, W(h)ither the Tax Gap?, 92 WASH. L. Rev. 521, 523-24 (2017):

[I] t seems far more probable that the tax gap will diminish in size in the future; that is, the tax gap may well "wither" away in size over the coming years. This prediction is based upon the following three significant trends. First, the use of credit cards, debit cards, and smartphone payment apps has become much more prevalent in economic commerce. This manner of conducting economic transactions creates an electronic (and traceable) trail of commerce and simultaneously subverts the driving engine behind many tax evasion activities, namely, the use of cash. Second, governments around the world, including the United States, have added new third-party compliance measures that take advantage of computer advances to monitor taxpayer economic activities so that the opportunity for taxpayers to pay less than they owe by mistake or by subterfuge has been and will continue to be dramatically reduced. Third, as business enterprises have grown in magnitude-in many instances eradicating small businesses-there is more direct and indirect tax compliance Id. oversight.

13. I.R.C. § $262(\mathrm{a})(2018)$. 
deep cuts in government services or entitlements or draconian tax increases.

In light of the workplace transformation, the public should better understand the nature of the problem, and politicians and bureaucratic administrators should respond by charting a course of action to address looming tax noncompliance. Part I of this analysis examines the Industrial and Technological Revolutions and how each has shaped the Code regarding the taxation of home-related expenses, as well as how the pandemic is having a similar effect. Next, Part II analyzes how a decentralized workplace, with the focal point being a taxpayer's home, is ripe with possible tax-avoidance opportunities. Part III offers possible legislative and administrative reform measures that Congress, the Treasury Department, and the IRS should consider instituting. Finally, this Article offers concluding thoughts.

\section{BACKGRound}

Over the course of the last century, the nation's workplace has continually evolved. In the beginning of the twentieth century, a huge swath of the nation's population was still working on farms and ranches, and most of the country was still largely rural. ${ }^{14}$ However, the mass production stage of the Industrial Revolution soon ignited, ${ }^{15}$ fundamentally changing where taxpayers worked and lived. ${ }^{16}$ A century later, the Technological Revolution and COVID-19 erupted, ${ }^{17}$ ushering in additional workplace

14. See Carolyn Dimitri, Anne Effland \& Neilson Conklin, The 20th Century Transformation of U.S. Agriculture and Farm Policy 2 (U.S.D.A. 2005), https://www.ers.usda.gov/webdocs/publications/44197/13566_eib3_1_.pdf [https://perma.cc/GGS4-Y73C] ("Early 20th century agriculture was labor intensive, and it took place on a large number of small, diversified farms in rural areas where more than half of the U.S. population lived.").

15. See Eric Niiler, How the Second Industrial Revolution Changed Americans' Lives, History, https://www.history.com/news/second-industrial-revolution-advances [https://perma.cc/3CX8-YS87] ("Technology has changed the world in many ways, but perhaps no period introduced more changes than the Second Industrial Revolution. From the late nineteenth to early twentieth centuries, cities grew, factories sprawled and people's lives became regulated by the clock rather than the sun.").

16. See, e.g., Freddie Wilkinson, Industrialization, Labor, and Life, NAT'L GeoGRAPHIC, https://www.nationalgeographic.org/article/industrialization-labor-andlife/12th-grade [https://perma.cc/DJK2-P589] (last updated Jan. 27, 2020) ("However, the rise of factory production and industrial cities meant a separation of the home from the workplace for most male workers. Very often, the need for income motivated men to leave their families behind for jobs in the city.").

17. See Umberto Colombo, The Technology Revolution and the Restructuring of the Global Economy, in Globalization of Technology: International Perspectives 23 (1988) (explaining the effects of the technological revolution); Derrick Bryson Taylor, A Timeline of the Coronavirus Pandemic, N.Y. Times (Mar. 17, 2021), https: //www.nytimes.com/article/coronavirus-timeline.html (explaining how the epidemic started). 
changes. ${ }^{18}$ As these societal events have unfolded, Congress has responded by racing to keep pace and adjusting the Code in ways that reflect these seismic changes.

Section A explores the implications associated with a workforce that experienced two major shifts: the first shift from working on family farms and ranches to working in a commercial work environment, and a second shift from a commercial work environment to working from home. Section B considers a key congressional effort to stem taxpayer workplace tax abuse by placing significant limitations on home office deductions.

\section{A. Workplace Evolution}

With the passage of the Sixteenth Amendment, ${ }^{19}$ Congress had the public's imprimatur to institute an income tax. Thus, in 1913, the nation's modern income tax came into being. ${ }^{20}$ However, with the Industrial Revolution still somewhat in its nascent stages of development, ${ }^{21}$ the Code's original statutory language failed to contemplate a meaningful separation between a taxpayer's workplace and home. ${ }^{22}$ This should not come as any surprise: at the turn of the century, a taxpayer's workplace and home were likely one in the same or, at least, not too physically distant. Virtually no one owned an automobile, ${ }^{23}$ and, instead, the primary available means of transportation were horse and buggy, ${ }^{24}$ steamboat, ${ }^{25}$ and passenger railcar. ${ }^{26}$

18. For a general overview of the workplace changes resulting from COVID19 , see supra note 2 and accompanying text.

19. U.S. Const. amend. XVI.

20. Revenue Act of 1913, Pub. L. No. 63-16, § II, 38 Stat. 114, 166-81 (1913).

21. Coincidentally, 1913 was the year Henry Ford introduced the first assembly line. Kat Eschner, In 1913, Henry Ford Introduced the Assembly Line: His Workers Hated It, Smithsonian Mag. (Dec. 1, 2016), https://www.smithsonianmag.com/ smart-news/one-hundred-and-three-years-ago-today-henry-ford-introduced-assembly-line-his-workers-hated-it-180961267/ [https://perma.cc/9G7N-WK2V].

22. The words travel and home are both absent from the first version of the modern income tax, thus, providing indirect evidence of Congress's failure to contemplate meaningful separation. See Revenue Act of 1913, supra note 20.

23. See Automobile History, Hist., https://www.history.com/topics/inventions/ automobiles [https://perma.cc/9FMP-MMPR] (last updated Aug. 21, 2018).

24. See Jenny Ashcraft, Horse and Buggy: The Primary Means of Transportation in the 19th Century, FishwraP (July 17, 2019), https://blog.newspapers.com/horseand-buggy-the-primary-means-of-transportation-in-the-19th-century [https:// perma.cc/T74J-TKNV] ("Horses and other animals including oxen and donkeys provided the primary means of transportation all over the world through the nineteenth century.").

25. Steamboats, National Geographic (July 10, 2016), https://www.national geographic.org/encyclopedia/steamboat/ [https://perma.cc/KS5E-DPLC] ("In the later years of the 19th century, larger steam-powered ships were commonly used to cross the Atlantic Ocean. ... Steamships became the predominant vehicles for transatlantic cargo shipping as well as passenger travel. Millions of Europeans immigrated to the United States aboard steamships.").

26. See Michael Goldstein, Is US Passenger Rail a Thing of the Past-or the Future?, Forbes (Dec. 6, 2019, 4:39 AM) https://www.forbes.com/sites/michaelgold 
Consider the language of the original Code and its rich generalities. It provided deductions for "the necessary expenses actually paid in carrying on any business" and specifically excluded "personal, living, or family expenses . ..." 27 What can be extrapolated from this simple verbiage was a basic precept: those taxpayers who worked and lived on traditional farms and ranches, along with those who began to venture into cities, could not deduct those expenses associated with maintaining their homes. ${ }^{28}$

During the twentieth century, the Industrial Revolution continued to blossom. ${ }^{29}$ At the same time, the nature of the nation's workforce dramatically shifted, as did the location where taxpayers generally resided. ${ }^{30}$ Over the decades that followed the introduction of the income tax, taxpayers left family farms and ranches in droves and entered the manufacturing sector of the economy. ${ }^{31}$ Furthermore, as automobiles became more readily available, ${ }^{32}$ the nation's highway system began to explode, ${ }^{33}$ and

stein/2019/12/06/is-us-passenger-rail-a-thing-of-the-past-or-the-future/ [https:// perma.cc/ZW7K-794X] ("In May of 1869, track-laying crews from Central Pacific working eastbound, and from Union Pacific working west, met at Promontory, Utah, creating a US transcontinental railroad. The railroad literally tied the country together, cutting what had been a four-month journey across the US to just seven days [and is] considered one of the greatest technical achievements of the 19th Century. ....").

27. Revenue Act of 1913, Pub. L. No. 63-16, § II(B), 38 Stat. 114, 167 (1913).

28. This guiding principle, namely, the need to maintain a strict demarcation line between business and personal expenses, has endured and has oriented Congress's legislative measures ever since. See, e.g., Krause, supra note 4, at 392 ("Distinguishing between business and personal expenses in calculating income tax deductions has long been a troublesome process in tax law.").

29. See, e.g., The Third Industrial Revolution, Economist (Apr. 21, 2012), https:/ /www.economist.com/leaders/2012/04/21/the-third-industrial-revolution [https://perma.cc/MH3F-KF7N] ("The second industrial revolution came in the early 20th century, when Henry Ford mastered the moving assembly line and ushered in the age of mass production.").

30. See, e.g., Leah Platt Boustan, Devin Bunten \& Owen Hearey, Urbanization in the United States, 1800-2000, at 4 (Nat'l Bureau of Econ. Research, Working Paper No. 19041, 2013), https://scholar.princeton.edu/sites/default/files/lboustan /files/research21_urban_handbook.pdf [https://perma.cc/M7LD-5RGJ] ("From 1830 to 1930 , the pace of urbanization substantially accelerated: the share of the population living in an urban area increased six-fold to [sixty] percent.").

31. See, e.g., Bradley Blackburn \& Eric Noll, Made in America: A Brief History of U.S. Manufacturing, ABC News (Feb. 14, 2011), https://abcnews.go.com/Business/made-america-middle-class-built-manufacturing-jobs $/$ story? id=12916118 [https://perma.cc/FVJ9-GW54] ("Industrialization changed the fabric of American life, encouraging workers to leave behind family farms and move closer to factories in cities and eventually suburbs.").

32. See generally James J. Flink, America Adopts the Automobile, 1895-1910 (M.I.T. Press, 1970) (describing how the introduction of the automobile fundamentally transformed society in the United States).

33. See generally Joseph Stromberg, Highways Gutted American Cities. So Why Did They Build Them?, Vox, https://www.vox.com/2015/5/14/8605917/highways-in terstate-cities-history [https://perma.cc/H3JK-3FJP] (last updated May 11, 2016) (describing how the automobile industry launched a political campaign to have the nation build a national highway system). 
taxpayers left their rural environs and transitioned into suburban and urban localities. ${ }^{34}$ Albeit subject to a healthy dose of speculation, the presumption is that this combined shift in the nature of the nation's workforce and those places where taxpayers migrated likely impacted the nature of tax deductions they sought.

On numerous occasions, Congress responded to these workforce and residential living shifts by updating the Code to correlate with the evolving economic landscape. Emblematic of such change is Code section 162(a) (2), which provides that, in carrying on any trade or business, deductions are permitted for "traveling expenses ... while away from home in the pursuit of a trade or business. . .." 35 Since its formulation in $1921,{ }^{36}$ this statutory language - and, in particular, the word home-has undergone intense judicial scrutiny. ${ }^{37}$ Notwithstanding the linguistic controversies that have swirled around the word home, its statutory presence constitutes a clear indication that taxpayers regularly travel away from their homes to conduct their business affairs, a phenomenon that was truly novel prior to the turn of the twentieth century for the vast majority of the nation's population.

Beyond Code section 162(a) (2), there are many other Code sections, Treasury regulations, and administrative rulings that touch upon the nature of the workplace and its evolution. ${ }^{38}$ Some Treasury regulations reflect the fact that, as a result of industrialization, taxpayers routinely commute from home to work. ${ }^{39}$ Finally, various IRS administrative rulings (e.g., revenue rulings and other pronouncements) offer guidance to tax-

34. See Boustan et al., supra note 30, at 3 ("Since the country's founding, the US population has been moving from rural to urban areas and from smaller towns to larger cities.").

35. I.R.C. § 162 (a) (2) (2018).

36. Revenue Act of 1921, ch. 136, § 214(a) (1), 42 Stat. 227, 239.

37. In many instances, the IRS has embraced the position that home refers to the taxpayer's business headquarters. E.g., Rev. Rul. 54-497, 1954-2 C.B. 75 ("Accordingly, it is now well-settled law that a taxpayer's 'home,' for purposes of this statute, is located at the place where he conducts his trade or business . . .."). Conversely, taxpayers have often averred that the word home means one's abode. See, e.g., Stidger v. Comm'r, 355 F.2d 294, 299 (9th Cir. 1965) ("'Home' in the statute . . means home in its ordinary and usual sense . ...”). For an excellent overview of the legal controversies involving this statute, see John A. Lynch, Jr., Travel Expense Deductions Under I.R.C. $\$ 162(A)(2)$-What Part of "Home" Don't You Understand?, 57 BAYLOR L. REv. 705 (2005).

38. Such Code sections include, but are not limited to Code sections 107, 11, and 132. I.R.C. $\$ 107$ (2018) (permitting a parsonage allowance for clergy homes); $i d$. $\S 119$ (a) (providing an income exemption for housing for employees who, as a condition of employment, must live on the business premises of their employer); $i d$. $\$ 132$ (a) (detailing a laundry list of workplace fringe benefits that are exempt from income taxation).

39. Treas. Reg. § 1.162-2(e) (1960). 
payers regarding the treatment of the expenses they incur when personal and business affairs are sometimes entwined. ${ }^{40}$

As the mass production phase of the Industrial Revolution peaked and then began to ebb, ${ }^{41}$ the Technological Revolution ${ }^{42}$ came into being, followed soon thereafter by the worldwide COVID-19 pandemic. ${ }^{43}$ The macroeconomic effects of these two events have been colossal, particularly as they pertain to the workplace and where taxpayers choose to reside. ${ }^{44}$ Among many effects, the Technological Revolution has greatly facilitated communication and has stripped physical work locations of their erstwhile preeminence. ${ }^{45}$ By way of example, taxpayers may now contact or reach others from virtually anywhere in the world, including from the peak of Mount Everest. ${ }^{46}$ Said somewhat differently, physical location is no longer an impediment or barrier to conducting fruitful and meaningful business affairs.

40. See, e.g., Rev. Rul. 99-7, 1999-1 C.B. 361 ("This ruling provides the rules for determining whether daily transportation expenses incurred by a taxpayer in going between the taxpayer's residence and a work location are deductible business expenses under section 162(a) of the Code.").

41. See Ryan Engelman, The Second Industrial Revolution, 1870-1914, U.S. Hist. ScEne, https://ushistoryscene.com/article/second-industrial-revolution [https:// perma.cc/H6M5-PTQB] (last visited Dec. 30, 2020) (describing how the second socalled Industrial Revolution unfolded).

42. See Elizabeth Schulze, Everything You Need to Know About the Fourth Industrial Revolution, CNBC, https://www.cnbc.com/2019/01/16/fourth-industrial-revolu tion-explained-davos-2019.html [https://perma.cc/Z929-NE3U] (last updated Jan. 22, 2019) ("Simply put, the Fourth Industrial Revolution [a.k.a. the Technological Revolution] refers to how technologies like artificial intelligence, autonomous vehicles and the internet of things are merging with humans' physical lives.").

43. See Taylor, supra note 17 (describing how the pandemic started, and then spread throughout the United States in 2020).

44. See, e.g., May Wong, Stanford Research Provides a Snapshot of a New Workingfrom-Home Economy, Stan. News (June 29, 2020), https://news.stanford.edu/2020/ 06/29/snapshot-new-working-home-economy [https://perma.cc/8Z5F-ZFZ6 ] ("The new 'working-from-home-economy,' which is likely to continue long past the coronavirus pandemic that spawned it, poses new challenges-from a ticking time bomb for inequality to an erosion of city centers. ....").

45. See, e.g., John Klein, Your Small Business May Not Need a Physical Office to Thrive, BizTech (Apr. 17, 2018), https://biztechmagazine.com/article/2018/04/ your-small-business-may-not-need-physical-office-thrive [https://perma.cc/UX2HU6JT]:

The office culture of yesteryear, in which workers came into an office at 9 a.m., sat down at a desk, worked all day and left around 5 p.m., is still around, but is rapidly fading. In its place, users are becoming more mobile as technology enables them to do work securely, from almost anywhere.

Id.

46. See Matt Hamblen, Everest Climber Reaches Summit, Makes First Cell Phone Call from There, COMPUTERWORLD (May 21, 2007), https://www.computerworld.com/ar ticle/2545344/ everest-climber-reaches-summit-makes-first-cell-phone-call-fromthere [https://perma.cc/8ZHU-6LNF]. 
The internet has made the workplace even more malleable and further blurred the yesteryear work-home dichotomy. ${ }^{47}$ More specifically, due to the internet, taxpayers are now able to conduct business from any laptop they wish. In addition, workers are no longer confined to when their offices are open; as long as they have electricity for their laptops or sufficient battery power, they are at liberty to work $24 / 7$. As a result of these technological changes that have unleashed the attractiveness of working from home, more taxpayers than ever have become unmoored from their office complexes. ${ }^{48}$

When COVID-19 struck, what was previously a matter of convenience for many, namely, working from home, became a matter of necessity as mandatory stay-at-home orders came into vogue. ${ }^{49}$ For white-collar business enterprises to survive, it became imperative that taxpayers comprising this economic sector conduct work from home. This emerging need coupled with the introduction of various internet platforms such as WebEx and Zoom, which made virtual meetings possible, ${ }^{50}$ led to the further diminishment of centralized workplaces. Furthermore, as cloud technology has advanced, taxpayers could secure immediate access to their important documents from anywhere in the world, including from the confines of their home. ${ }^{51}$

47. See Adi Gaskell, Is a Blurred Work-Life Balance the New Normal?, Forbes (May 11, 2020), https://www.forbes.com/sites/adigaskell/2020/05/11/is-a-blurredwork-life-balance-the-new-normal/?sh=4c25874f1813 [https://perma.cc/DK9A2A3X] (describing how work life and home life are further intersecting due to technology and the pandemic).

48. See, e.g., Bill George, The Coronavirus Pandemic Is Changing Work Forever, Fortune (Apr. 10, 2020), https://fortune.com/2020/04/10/coronavirus-pandemic-changing-work [https://perma.cc/3SQ7-XJDH]:

The pandemic has shown more people they can easily work from home, relying on email, chats, and videoconferencing to quickly communicate with colleagues. Many employees won't return to the office even after the pandemic is under control-and the need for physical workspaces and paper files will decrease. Instead, many more people will work from Id. home, fully wired on mobile phones, laptops, and other devices.

49. See Sarah Mervosh, Denise Lu, \& Vanessa Swales, See Which States and Cities Have Told Residents to Stay at Home, N.Y. Times, https://www.nytimes.com/interactive/2020/us/coronavirus-stay-at-home-order.html [https://perma.cc/FA57CFFA] (last updated Apr. 20, 2020).

50. See, e.g., David Gelles, Logged on from the Laundry Room: How the C.E.O.s of Google, Pfizer and Slack Work from Home, N.Y. Times (Mar. 23, 2020), https:// www.nytimes.com/2020/03/23/business/corner-office-coronavirus.html [https:// perma.cc/F2UU-D8D3] ("Cisco, which makes networking equipment, has seen demand for its Webex video conferencing system spike.").

51. See, e.g., Hugh Armitage, Five Benefits of Cloud Document Storage for Remote Working, ITPRO (Apr. 9, 2021), https://www.itpro.co.uk/cloud/cloud-storage/ 356546/5-benefits-of-cloud-document-storage-for-remote-working [https:// perma.cc/FK97-ZNPR]:

But thanks to the 2020 coronavirus pandemic and the subsequent move to mass remote working for both IT teams and the wider workforce, the cloud has certainly been given a chance to shine (a Snow Software survey 
Over the course of the last two decades, as the Technological Revolution has progressed, Congress has not been oblivious to the changes that technology has generated. To the contrary, it has sought to incorporate technological advancements into the Code's fabric. Consider various manifestations of how Congress has employed technological know-how. When it comes to taxpayer compliance, for example, Congress recognizes that third-party tax information returns (e.g., Form W-2s and 1099s) are central to keeping taxpayers compliant. Statistics affirm this claim: when third-party tax information returns are present, taxpayer compliance is high (the underreporting percentage is below ten percent); and, by contrast, in the absence of third-party tax information return reporting, taxpayer compliance plummets (the underreporting percentage is over sixty percent). ${ }^{52}$ Over the years, Congress has therefore expanded the use of such third-party information returns. ${ }^{53}$ Congress has also capitalized on other technological advances, for example, by promoting electronic tax return submissions and, in some cases, mandating their use. ${ }^{54}$

Beyond capitalizing upon technological changes to facilitate how administrative functions are carried out, Congress has been attentive to the role that technology has played in shaping the workplace. Technology has shifted the economy from manufacturing to "neurofacturing"- a term coined by economists Edward E. Leamer and J. Rodrigo Fuentes to describe intellectually intensive white-collar labor that is often connected to the internet, such as software programming, marketing, advertising, consulting, and publishing. ${ }^{55}$ Neurofacturing permits long hours because the jobs associated with it are "less physically arduous, as it's easier to sit and

found that $82 \%$ of IT leaders increased their cloud usage in response to COVID-19). Id.

52. See Cong. Budget Office, Trends in the Internal Revenue Service's Funding AND ENFORCEMENT, at fig.4 (July 2020), https://www.cbo.gov/publication/56467\#footnote-062-backlink [https://perma.cc/DV5Z-372V]; see also Leandra Lederman \& Joseph C. Dugan, Information Matters in Tax Enforcement, 2020 B.Y.U. L. REv. 145, 145-46 (explaining that "government needs information about taxpayers' transactions in order to determine whether their reporting is honest" and that third-party reporting helps the government obtain that information); Joel Slemrod, Cheating Ourselves: The Economics of Tax Evasion, 21 J. Econ. Persps. 25, 37 (2007) (correlating "the rate of compliance and the presence of enforcement mechanisms such as information reports and employer withholding").

53. See, e.g., Jay A. Soled, Homage to Information Returns, 27 VA. TAx Rev. 371, 373 (2007) ("[I]n 1982, Congress passed the Tax Equity and Fiscal Responsibility Act of 1982 (TEFRA), which required that brokers delineate the gross proceeds arising from securities and commodities transactions on information return forms.").

54. See, e.g., Taxpayer First Act, Pub. L. No. 116-25, § $3101($ a), 133 Stat. 981 (2019) (requiring exempt organizations to electronically file their information returns and related forms for tax years beginning after July 1, 2019).

55. Derek Thompson, Why White-Collar Workers Spend All Day at the Office, ATLANTIC (Dec. 4, 2019), https://www.theatlantic.com/ideas/archive/2019/12/howinternet-enables-workaholism/602917 [https://perma.cc/EF6S-2P3V]. 
type than to assemble engine parts." 56 As workdays have become longer, on-the-job taxpayers have demanded a cornucopia of fringe benefits to make their workdays more pleasant. And, as a form of compensation in lieu of paying higher wages (which, in turn, would have generated additional payroll taxes), ${ }^{57}$ their employers were eager to make this accommodation.

Thus, as employers increasingly showered their employees with putative nontaxable fringe benefits, Congress took countermeasures to curtail such practices. To prevent an erosion of the income tax base as a result of this workplace change, Congress instituted Code section 132.58 In a comprehensive fashion, this Code section delineates those fringe benefits that are exempt from tax and, by default, all others that are not. ${ }^{59}$ The introduction of Code section 132 symbolizes the fact that Congress tries to stay attuned to workplace adjustments.

\section{B. Evolution of the Deductibility of Home Office Expenses}

Over the course of the last century, when it comes to the income tax, Congress has constantly sought to maintain a hard-and-fast distinction between business and personal expenses. ${ }^{60}$ Accordingly, as the workplaceand thus home office use-has evolved, Congress has been circumspect regarding the deductibility of expenses associated with home offices. This Section explores home office deductions and what Congress has done to keep those deductions in check.

By its nature, the use of one's home constitutes personal consumption; and, as such, the expenses associated with its maintenance and upkeep (e.g., utilities, insurance, and general repairs) are nondeductible. ${ }^{61}$ If, however, taxpayers choose to utilize one or more rooms or living spaces in their homes for business use, the calculus changes. In such cases, the

56. Id.

57. See I.R.C. $\$ 3111$ (a)-(b) (2018) (imposing both a 6.2\% old-age, survivors, and disability insurance tax and a $1.45 \%$ hospital insurance tax on wages that employers pay).

58. I.R.C. § 132 (a) (2018).

59. Id. If the fringe benefit does not fall within the scope of this section, it constitutes taxable income. See Treas. Reg. \$1.61-21(a) (1989) ("Section 61(a) (1) provides that, except as otherwise provided in subtitle A of the Internal Revenue Code of 1986, gross income includes compensation for services, including fees, commissions, fringe benefits, and similar items.").

60. Compare I.R.C. $§ 162$ (a) (2012) (allowing "ordinary and necessary" business expenses), with I.R.C. $\$ 262$ (a) (disallowing personal consumption). When the distinction between the two could become blurred (e.g., business meals), Congress imposes special limitations. See I.R.C. § 274(n) (limiting the allowable deduction to fifty percent of the expense incurred).

61. I.R.C. § 262; see, e.g., Cottrell v. Comm'r, T.C. Summary Opinion 2008-101 (holding taxpayer's purchase of tools and supplies used to make home improvements were not deductible). 
Code permits taxpayers to use the concomitant expenses they incur to offset the income they earn. ${ }^{62}$

Assets such as homes, cellular phones, computers, and automobiles sometimes combine business and personal use and are commonly referred to as "mixed-use assets." ${ }^{3}$ Because such assets are vulnerable to taxpayer abuse, on numerous occasions Congress has instituted legislative safeguards pertaining to deductions associated with their use. ${ }^{64}$

The history of home office deductions illustrates congressional sensitivity to the issue of mixed-use assets and Congress's search to strike the appropriate balance between allowing justified business expenses and casting a watchful eye over potential taxpayer abuse. Subsection 1 explores the legislative landscape prior to dedicated home office deduction legislation, and Subsection 2 details Congress's attempt to clarify what has proven to be an elusive area of the law.

\section{Legislative Landscape Prior to the Introduction of the Home Office Deduction}

From the inception of the modern income tax and for many decades thereafter, home office deductions were handled under the catchall category of "ordinary and necessary" business expenses found in Code section 162(a). ${ }^{65}$ In 1962, via an administrative ruling to clarify this area of the law, the IRS issued the following pronouncement:

The deductible expenses of an employee, whose conditions of employment are such that he regularly uses a part of his residence in the performance of his duties as an employee, include a pro rata portion of such items as rent, light, taxes, and interest

62. See Hantzis v. Comm'r, 638 F.2d 248, 249 (1st Cir. 1981) (“[A] person’s taxable income should not include the cost of producing that income."); Note, The Additional Expense Test: A Proposal to Help Solve the Dilemma of Mixed Business and Personal Expenses, 1974 Duke L.J. 636, 636 (1974) ("The policy underpinning [Code section 162] reflects the traditional congressional concern that costs of producing income should not be included in net income, i.e., in the amount upon which the tax is levied.").

63. Assets of this sort have a binary use: sometimes for business and other times for personal. See David R. Burton \& Dan R. Mastromarco, The National Sales Tax-Moving Beyond the Idea, 71 TAx Notes 1237, 1246 (1996) (defining mixed-use assets).

64. See I.R.C. $\S 280 \mathrm{~F}(\mathrm{~d})(4)$ (A) (offering a definition of listed property to include items such as "any passenger automobile" and "any property of a type generally used for purposes of entertainment, recreation, or amusement").

65. See, e.g., Sharon v. Comm'r, 66 T.C. 515, 522 (1976), aff'd, 591 F.2d 1273 (9th Cir. 1978) ("The petitioner contends that one-sixth of such payments is deductible under either section 162(a) or section 212. The Commissioner, on the other hand, argues that such expenditures were personal in nature and are nondeductible under section 262.”); Kelly v. Comm'r, 23 T.C.M. (CCH) 472 (1964) (holding that taxpayer failed to prove that his home office use was born out of business necessity under Code section 162(a) and hence associated expenses were nondeductible). 
on a mortgage. No portion of purely personal expenses attributable to family household purposes are deductible. ${ }^{66}$

The ruling further elaborated that for expenses attributable to one's home to be deductible, its business use had to be "regular and not merely incidental or occasional." 67 As a concession to taxpayers, the ruling acknowledged that expense deductibility was possible even if the living spaces in question were not exclusively used for business, providing six comprehensive examples that illustrated this point. ${ }^{68}$

Years later, the judiciary weighed in on the nature of the deductibility of home office expenses. In Newi $v$. Commissioner, ${ }^{69}$ a taxpayer, a salesman of television time, resided in a four-room apartment and used one room therein extensively for his business. ${ }^{70}$ The choice of the taxpayer's workplace location, however, was a voluntary choice insofar as his employer's offices remained open for the taxpayer's use. On the taxpayer's tax return, he nevertheless deducted the portion of his rental expense, cleaning, and lighting related to the business use of his workroom. Upon audit, the commissioner disallowed the deductibility of such expenses, claiming that the use of this room was instead for personal convenience rather than born out of business necessity. The Tax Court sided with the taxpayer, holding that because the expense was " appropriate and helpful' to the taxpayer's business," it was deductible. ${ }^{71}$ The Second Circuit upheld this decision, extolling the merit of the "appropriate and helpful" standard to determine deductibility. ${ }^{72}$

But the taxpayer-friendly "appropriate and helpful" standard opened the floodgates of taxpayers seeking home office deductions. ${ }^{73}$ As courts continued to intervene, they had to weigh the personal convenience versus business necessity of taxpayers utilizing their home offices. By way of example, in Bodzin v. Commissioner, ${ }^{74}$ the taxpayer was an IRS employee who maintained a small office in his apartment to work on litigation matters and study legal trends. While the taxpayer's employer provided office facilities for the taxpayer's use, the taxpayer's home office was far more convenient. On this basis, utilizing the "appropriate and helpful" standard, the Tax Court ruled in the taxpayer's favor. ${ }^{75}$ However, on appeal,

66. Rev. Rul. 62-180, 1962-2 C.B. 52.

67. $I d$.

68. $I d$.

69. 432 F.2d 998 (2d Cir. 1970).

70. See, e.g., $i d$. at 999 (noting that on a regular basis, the taxpayer spent time "reviewing his notes on the day's selling activities, studying various research materials and ratings, making his plans for the next day's work, and viewing the television advertisements of [his employer] and its competitor networks.").

71. Newi v. Comm'r, 28 T.C.M. (CCH) 686 (1969).

72. Newi, 432 F.2d at 1000 .

73. As of December 31, 2020, thirty-six subsequent cases have cited the Newi decision.

74. 509 F.2d 679 (4th Cir. 1975).

75. Bodzin v. Comm'r, 60 T.C. 820, 826 (1973). 
the Fourth Circuit disagreed, stating that the personal consumption element predominated the taxpayer's motives, and hence the expenses in question were nondeductible. ${ }^{76}$ The Fourth Circuit emphasized the fact that the taxpayer "did not use any part of his apartment as his place of business; like most lawyers and judges, he sometimes, by choice, did some of his reading and writing at home." 77

As a complement to the "appropriate and helpful" standard, courts have routinely engaged in a fact-and-circumstance inquiry, seeking to determine whether a taxpayer's choice to create a home office was driven primarily by business exigencies or largely for reasons of personal convenience. In the latter cases, courts normally have held home office expenses to be nondeductible. ${ }^{78}$ In the words of the Tax Court, when the business use of a home is truly "for reasons of "personal convenience, comfort, or economy[,]" it will not support a deduction under section $162(\mathrm{a}) .{ }^{79}$

For years, taxpayers continued to take home office deductions based upon the vague "appropriate and helpful" standard, shaped by the "fact and circumstance" test. And, yes, the IRS could challenge the most egregious cases of taxpayer abuse, but audits of this sort are burdensome. ${ }^{80}$

\section{Code Section 280A: Introduction of the Home Office Deduction}

In light of all the litigation swirling around home office deductibility, Congress recognized that continued inattentiveness to this issue was problematic. Therefore, in 1976, Congress instituted a legislative measure to clarify this area of the law and to offer objective deduction standards. ${ }^{81}$

This legislative measure is embodied in Code section 280A. It starts with a blanket declaration that prohibits any deduction associated with the "use of a dwelling unit which is used by the taxpayer during the taxable

76. Bodzin, 509 F.2d at 681 ("We conclude that the expense of renting the Bodzin's apartment was a personal expense within the meaning of $\S 262$ and not a business expense.”).

77. $I d$.

78. See Lucke v. Comm'r, 39 T.C.M. (CCH) 478, 481 (1979):

In weighing and balancing all the facts in this record, we conclude that here .... [the taxpayer's] desk, bookshelves and phone did not constitute a "place of business." [And the taxpayer] incurred no additional expense by having a desk in one corner of his bedroom, and his incidental use of that space as a convenient place to keep abreast of tax trends Id.

does not convert a personal expense into a business expense. 1978).

79. Sharon v. Comm'r, 66 T.C. 515, 525 (1976), aff'd, 591 F.2d 1273 (9th Cir.

80. See Ridgeley A. Scott, Reimbursed Employee Expenses: New Tales from the Grimm Brothers, 28 Willamette L. Rev. 1, 8 (1991) (explaining how some IRS audits are more time-intensive than others).

81. See Tax Reform Act of 1976, Pub. L. No. 94-455, tit. VI, §601(a), 90 Stat. $1520,1569$. 
year as a residence." 82 The statute then provides three important exceptions for that portion of a dwelling unit that is "exclusively used on a regular basis" for any one the following three activities:

(A) as the principal place of business for any trade or business of the taxpayer,

(B) as a place of business which is used by patients, clients, or customers in meeting or dealing with the taxpayer in the normal course of his trade or business, or

(C) in the case of a separate structure which is not attached to the dwelling unit, in connection with the taxpayer's trade or business. ${ }^{83}$

In the case of employees, the statute posits one additional requirement for any of these exceptions to apply: the work performed at the taxpayer's dwelling unit must be for the employer's convenience. ${ }^{84}$ This statute crystallized Congress's efforts to clarify this area of the law and put an end to the groundswell of home office deduction litigation. ${ }^{85}$

Notwithstanding congressional good-faith intent, Code section 280A spawned a whole new wave of litigation. In particular, in the minds of many taxpayers, it was unclear what Congress meant by its use of the phrase principal place of business. ${ }^{86}$ In a case of first impression, Baie v. Com-

82. I.R.C. $§ 280 \mathrm{~A}(\mathrm{a})(2012)$.

83. Id. $\S 280 \mathrm{~A}(\mathrm{c})(1)$.

84. See id.

85. Both the House and Senate reports related to the enactment of Code section 280A reflect congressional frustrations about, due to its subjective nature, the "appropriate and helpful" test. H.R. ReP. No. 94-658, at 160 (1975), as reprinted in 1976 U.S.C.C.A.N. 2897, 3053:

In many cases the application of the appropriate and helpful test would appear to result in treating personal living, and family expenses which are directly attributable to the home (and therefore not deductible) as ordinary and necessary business expenses, even though those expenses did not result in additional or incremental costs incurred as a result of the business use of the home. Thus, expenses otherwise considered nondeductible personal, living, and family expenses might be converted into deductible business expenses simply because, under the facts of the particular case, it was appropriate and helpful to perform such portion of the taxpayer's business in his personal residence.

Id.; see also S. REP. No. 94-938, at 147 (1976), as reprinted in 1976 U.S.C.C.A.N. 3439, 3579. Indeed, Congress enacted section 280A to provide "definitive rules relating to deductions for expenses attributable to the business use of homes." S. REP. No. 94-1236 (1976) (Conf. Rep.), 1976-3 C.B. (Vol. 3) 807, 839; see also H. Rep. No. 94658 (1976), 1976-3 C.B. (Vol. 2) 695, 852; S. Rep. No. 94-938 (1976), 1976-3 C.B. (Vol. 3) 49, 185; Staff of the Joint Comm. on Taxation, 94th Cong., Gen. Explanation of the Tax Reform Act of 1976, 1976-3 C.B. (Vol. 2) 1, 151.

86. See, e.g., Mark T. Holtschneider, Putting the House in Order: An Analysis of and Planning Considerations for Home Office Deduction, 14 U. BALt. L. Rev. 522, 531 (1985) ("Perhaps no other area involving section 280A creates more litigation than the 'principal place of business' exception."). 
missioner, ${ }^{87}$ the Tax Court introduced the so-called focal point test. In Baie, the taxpayer operated a small hot dog stand, and, while at home, she used her kitchen to prepare food and another part of her home for bookkeeping and administrative activities. ${ }^{88}$ On the basis of what it referred to as the "focal point test," it undertook a factual inquiry to determine which location was most important to the sustainability of the taxpayer's business. On the basis of this inquiry, it held that the taxpayer's hot dog stand, not her home, was the true focal point of her business and thus held that the home office expenses were not deductible because her home was deemed not to be the principal place of business.

But courts did not apply the focal point test in a consistent manner, and some just chose to ignore it. Regarding the test's lack of uniformity, in Drucker v. Commissioner, ${ }^{89}$ for example, the taxpayer was a concert violinist with the Metropolitan Opera Association. He set aside one room in his house to practice his instrument and deducted the rent, electricity, and maintenance costs associated with its use. The Tax Court disallowed these deductions because home practice was not "a requirement or condition of employment" mandated by the taxpayer's employer. ${ }^{90}$ Furthermore, the court ruled that the taxpayer's principal place of business was Lincoln Center, not his home. The Second Circuit, however, overturned the Tax Court's decision on the basis of the statute's legislative history. ${ }^{91}$ It found that the taxpayer spent the majority of his time practicing his musical skills at his home. ${ }^{92}$ On the basis of this factual finding, the Second Circuit deemed the taxpayer's home to be his focal point of business.

Regarding when courts chose to ignore the focal point test, in Meiers v. Commissioner ${ }^{93}$ for example, two married taxpayers operated a laundromat, spending an average of an hour a day on the business premises and two hours a day at home utilizing a dedicated room in their home to draft

87. 74 T.C. 105 (1980)

88. Id. at 107:

Because of the extremely cramped nature of the premises from which the selling was done, Mrs. Baie found it necessary to prepare food in the kitchen of her home, located seven-tenths of a mile from the Gay Dog, and to transfer the food and other supplies daily from her home to the hotdog stand. Mrs. Baie did all of her bookkeeping in another room in Id. her home used exclusively for that purpose.

89. 79 T.C. 605 (1982), rev'd, 715 F.2d 67 (2d Cir. 1983).

90. Id. at 608 .

91. Drucker v. Comm'r, 715 F.2d 67, 69-70 (2d Cir. 1983) ("In enacting section 280A, Congress intended to provide clearer standards for deductions and to prevent the conversion of nondeductible personal, living, and family expenses into deductible business expenses. The changes were not directed at taxpayers such as appellants." (citation omitted)).

92. Id. at 69 ("The place of performance was immaterial so long as the musicians were prepared, and most of the preparation occurred at home. The home practice areas were appellants' principal places of business within the meaning of section 280A.”).

93. 49 T.C.M. (CCH) 136 (1984), rev'd, 782 F.2d 75 (7th Cir. 1986). 
employee work schedules and perform certain bookkeeping duties. ${ }^{94}$ On the basis of the focal point test, the Tax Court disallowed the taxpayers' home office deduction, pointing out that the crux of the taxpayers' business was providing services to customers at the laundromat, not the behind-the-scenes, back-office administrative responsibilities that the taxpayers fulfilled at home. ${ }^{95}$ The Seventh Circuit reversed, however, expressing its misgivings about the focal point test and questioning its fairness. ${ }^{96}$ Instead, the Seventh Circuit emphasized the fact that the taxpayers were not "attempting to convert non-deductible personal living expenses into deductible business expenses." 97 Therefore, the court held that disallowing such deductions would not help further the congressional goal for enacting Code section 280A, which was primarily to safeguard the income tax base.

A subsequent battle between the IRS and a taxpayer offered the opportunity to clarify these muddied judicial waters. In Commissioner $v$. Soliman, ${ }^{98}$ the taxpayer was an anesthesiologist who spent the vast majority of his workweek administering anesthesia to patients at three different hospitals with which he was affiliated. He also spent several hours a week using a home office to fulfill administrative tasks related to his anesthesiology practice. On the taxpayer's tax return, he deducted condominium fees, utilities, and depreciation expenses associated with his home office use. On audit, the IRS challenged this position. The Tax Court sided with the taxpayer, allowing the office deductions on the basis that the taxpayer's home constituted his principal place of business ${ }^{99}$ - a position that the Fourth Circuit affirmed. ${ }^{100}$

Enter the Supreme Court. As might be expected based on precedent, the first thing the Court did was turn to Webster's Third New International

94. 49 T.C.M. (CCH) 136, 137 (1984):

Sally worked at the laundromat for about an hour each day, during which time she met with the employees, collected money from the machines, filled the change machines, and assisted customers. Sally's primary responsibility with respect to ALC, however, was to do the bookkeeping and other managerial tasks associated with the business such as counting the money and scheduling employees to work. For this purpose, petitioners maintained an office in a separate room in their home, which consisted of a desk, filing cabinet, safe, change counter, and sofa. Sally used this office for approximately two hours every day to do ALC's bookkeeping and also for about five minutes each month to account for two rental Id. payments received by $\mathrm{J} \& \mathrm{~J}$ and one mortgage payment issued by $\mathrm{J} \& \mathrm{~J}$.

95. 49 T.C.M. (CCH) 136 (1984) ("Although petitioners did use one room in their home exclusively for business purposes, the home office was not petitioners' principal place of business.").

96. 782 F.2d at 79 ("We, like the Second Circuit, question the usefulness of the focal point test.").

97. Id.

98. 506 U.S. 168 (1993).

99. Soliman v. Comm'r, 94 T.C. 20 (1990).

100. Soliman v. Comm'r, 935 F.2d 52 (4th Cir. 1991). 
Dictionary. ${ }^{101}$ It found that the dictionary defined the word principal to mean "most important, consequential, or influential." 102 Based upon this definition, the Supreme Court implied that when applying Code section 280A, a comparison of locations must be undertaken to decide which business location is principal. To assist in this endeavor, the Court proffered two interwoven tests: "[(i)] the relative importance of the activities performed at each business location and [(ii)] the time spent at each place." 103 In applying the first test, the Court instructed "that the point where goods and services are delivered must be given great weight in determining the place where the most important functions are performed." 104 The second test-pertaining to the amount of time spent at different locations-helps inform the first test, namely, the amount of time spent at a location likely signifies its relative importance. Applying these two tests, the commissioner prevailed, and the taxpayer's home office expenses were disallowed. The Court concluded the principal element of the taxpayer's work involved working with patients at the hospital, not administrative paperwork. ${ }^{105}$ Furthermore, the relative importance of this aspect of the taxpayer's practice was affirmed by the threefold amount of time he spent working at hospitals versus the relatively small amount of time he spent at his home office. ${ }^{106}$

At the time, the Soliman decision was greeted with a torrent of criticism. ${ }^{107}$ Some commentators claimed that it produced inequitable results 1981).

101. Principal, Webster's Third New International Dictionary 1802 (3d ed.

102. Soliman, 506 U.S. at 174.

103. Id. at 175 .

104. Id.

105. Id. at 178:

The actual treatment was the essence of the professional service. We can assume that careful planning and study were required in advance of performing the treatment, and all acknowledge that this was done in the home office. But the actual treatment was the most significant event in the professional transaction. The home office activities, from an objective standpoint, must be regarded as less important to the business of the Id. taxpayer than the tasks he performed at the hospital.

106. Id. at 178-79:

A comparison of the time spent by the taxpayer further supports a determination that the home office was not the principal place of business. The 10 to 15 hours per week spent in the home office measured against the 30 to 35 hours per week at the three hospitals are insufficient to render the home office the principal place of business in light of all of Id. the circumstances of this case.

107. See, e.g., Lauren Marini, Note, "Simplification" Is Not Enough: An Analysis of the Home Office Tax Deduction and the Home Office Simplification Act of 2009, 40 U. BALt. L. Rev. 107, 119 (2010):

The Soliman decision was widely criticized because it denied home office deductions to taxpayers with valid claims. Critics argued that Soliman resulted in different treatment for taxpayers who are similarly situated and 
between and among different work classifications. For example, lawyers, accountants, architects, and other like professionals could have bona fide home offices and could deduct the expenses associated with their use because of the nature of the work they are able to perform there. Conversely, other kinds of workers, such as landscapers, painters, and morticians, would be precluded from having bona fide home offices because the most important elements of their jobs could only be completed outside of their homes. ${ }^{108}$ In addition, other commentators thought the decision was flawed from a theoretical perspective because in Soliman the taxpayer truly was incurring expenses to generate more income-a bona fide indicium of a deductible expense. ${ }^{109}$

Congress responded to these critiques by revamping and liberalizing Code section 280A. In the Taxpayer Relief Act of 1997, Congress decided that taxpayers such as Soliman and those who are similarly situated should be entitled to deduct the expenses related to their home office. ${ }^{110}$ It therefore engrafted the following sentence to Code section 280A:

For purposes of subparagraph (A), the term "principal place of business" includes a place of business which is used by the taxpayer for the administrative or management activities of any trade or business of the taxpayer if there is no other fixed location of such trade or business where the taxpayer conducts substantial administrative or management activities of such trade or business. ${ }^{111}$

Beyond the Soliman decision itself, there were macroeconomic forces that were driving the introduction of this amendment as well. The legislative history behind this amendment points to two: first, more taxpayers

did not provide a predictable or workable standard for determining whether a taxpayer was eligible for the home office tax deduction.

Id.

108. See Brenda A. Ray, Home Office Deduction in Need of Repair: Applying MixedUse Allocation Theory to Internal Revenue Code Section 280A(c), 60 Oніо ST. L.J. 199, 214 (1999):

Yet, the application of the Soliman decision results in an unequal impact among taxpayers in different types of businesses. For example, under Soliman, home office deductions are completely denied for taxpayers such as house painters, carpenters, landscapers, construction workers, doctors, professors, musicians, artists, and sales professionals. Lawyers and accountants are unharmed, however, by the Soliman decision.

Id. (footnote omitted).

109. See Rhonda M. Abrams, Don't Give Up Home Office Deduction, GannetT News SErv. (1993), 1993 WL 7312900 (criticizing Soliman for favoring those taxpayers who rent versus those who use their homes for business purposes); Joan M. Harvath, Federal Tax Law-Home Office Deduction Narrowed: Commissioner v. Soliman, 77 MarQ. L. Rev. 179, 195 (1993).

110. See H.R. ReP. No. 105-148, at 407 (1997), reprinted in 1997 U.S.C.C.A.N. 678, 801 (expressing Congress's misgivings that deductions were not being afforded to "taxpayers who manage[d] their business activities from their homes").

111. I.R.C. $§ 280 \mathrm{~A}(\mathrm{c})(1)(2012)$. 
were choosing to avoid the headaches associated with commuting and spending more time with their families at home; ${ }^{12}$ second, technological advances were opening more doors than ever for taxpayers to be able to perform important work tasks at home with efficiency and alacrity. ${ }^{113}$

With this background in mind, it is important to recognize that technology and the scourge of the COVID-19 pandemic have vastly accelerated the pace of those wishing to work from home. ${ }^{114}$ The question that arises is whether the Code, last amended a quarter century ago, adequately safeguards the income tax base. Another way of framing this question is whether Code section $280 \mathrm{~A}$ can, in the twenty-first century, be the same bulwark that it was in the twentieth century. The next part of this analysis delves into this issue.

\section{Issues Associated with the Tax Deductibility of Home Office UsE}

Like any other mixed-use asset, ${ }^{115}$ home office use warrants heightened scrutiny. The IRS must inspect the legitimacy of taxpayer deductions, the judiciary has to employ the standards specified under Code section $280 \mathrm{~A}$ to determine the legality of taxpayer deductions, and Congress must ensure that the legislative landscape mirrors current taxpayer needs.

The sections below investigate these issues from two distinct vantage points: (A) problems associated with Code section 280A and (B) tax-avoidance opportunities associated with the current workplace transformation trend.

\section{A. Problems Associated with Code Section 280A}

Like any remedial legislation, Code section 280A has its shortcomings. Consider three in particular.

112. See H.R. 105-148, supra note 110, at 407 (noting that amending the statute would "enabl[e] more taxpayers to work efficiently at home, save commuting time and expenses, and spend additional time with their families").

113. Id. (noting that this amendment would enable taxpayers to capitalize on the "computer and information revolution").

114. See Megan Brenan, COVID-19 and Remote Work: An Update, Gallup (Oct. 13, 2020), https://news.gallup.com/poll/321800/covid-remote-work-update.aspx [https://perma.cc/NXQ9-W58T] ("Nearly two-thirds of U.S. workers who have been working remotely during the pandemic would like to continue to do so.").

115. See Ray, supra note 108:

Cars are generally personal assets, but they can also be used for business purposes. To determine the amount of the business deduction, an allocation is made to divide the mixed-use of the car into its business and personal use components. The actual use of the car for business purposes may be deductible, while the remaining personal use is a nondeductible personal expense.

Id. at $201 \mathrm{n} .5$ (citation omitted). 
First, the statute distinguishes between taxpayers who are employees versus those who are self-employed. ${ }^{116}$ In cases of the former, taxpayers must prove that working from home is "for the convenience of [their] employer." 117 From the vantage point of many traditional employees, however, assuming that they have a dedicated office at their employer's place of business, this requirement eliminates the availability of the home office deduction. Under such circumstances, the home offices that such employees maintain are deemed matters of mere personal convenience, and any expenses associated with their use are nondeductible. ${ }^{118}$ Thus, as a practical matter, the "convenience of the employer" requirement has historically put self-employed taxpayers in a far better position to procure tax-efficient outcomes than their employee counterparts. ${ }^{119}$

Second, some taxpayers whose home offices may qualify for this deduction hesitate to capitalize upon it because of its complexity and its concomitant substantiation requirements. ${ }^{120}$ When it comes to home office deductions, the fact that the IRS publication pertaining to it spans thirtyfive pages of single-spaced prose speaks volumes regarding its intricacies. ${ }^{121}$ Therefore, taxpayers whose home office expenses are deductible

116. I.R.C. $§ 280 \mathrm{~A}(\mathrm{c})(1)$.

117. See, e.g., Whitehurst v. Comm'r, T.C. Summ. Op. 2003-7:

For tax years beginning after December 31, 1998, in the case of an employee, the exclusive use must be for the convenience of his employer, and the term "principal place of business" includes a place of business which is used by the taxpayer for the administrative or management activities of a trade or business if there is no other fixed location of such trade or business where the taxpayer conducts substantial administrative or management activities.

Id. at 12 (citing I.R.C. $§ 280 \mathrm{~A}(\mathrm{c})(1)$ ).

118. See, e.g., Weightman v. Comm'r, 42 T.C.M. (CCH) 104 (1981).

Just as we have done in other cases involving teachers, we must conclude that petitioner's principal place of business was the school and not his office in his home. Moreover, petitioner has not established that his use of a home office was for the convenience of his employer. For these reasons, petitioner is not entitled to a deduction for the expenses connected with his office in the home.

Id. (footnotes omitted).

119. Consider the plight of two taxpayers: (i) a law professor who lives thirty minutes from the school, teaches six hours a week, and weekly conducts from his home office thirty hours of research; and (ii) an educational tutor who is selfemployed and, for approximately thirty hours weekly, travels from house to house to render their services and maintains a home office where they weekly spends six hours doing administrative and bookkeeping tasks on the business's behalf. Notwithstanding the vast difference in the amount of time spent at each one's home office, the expenses of the former would not be deductible, but those of the latter would be. See Marini, supra note 107, at 123-25.

120. See id. at 126-27.

121. See I.R.S. Pub. 587 (Jan. 14, 2021), https://www.irs.gov/pub/irs-pdf/ p587.pdf [https://perma.cc/56YW-NK8A] [hereinafter Publication 587]. Admittedly, the IRS has introduced a simplified home office deduction method that taxpayers can use, but it caps allowable deductions at \$1,500. Rev. Proc. 2013-13, 2013-6 I.R.B. 478. 
have to annually endure the tiresome and laborious task of making this computation, or else pay a professional to do so on their behalf. Beyond undertaking these challenging deduction computations, if audited by the IRS, taxpayers must be able to produce documentation that supports the legitimacy of their deductions. ${ }^{122}$

Finally, the statute requires that the taxpayer's use of the home office be "regular," a word which is infused with ambiguity. The IRS's publication regarding home office deductions instructs taxpayers wishing to meet the "regular use test" to employ a "specific area of [their] home for business on a regular basis. Incidental or occasional business use is not regular use." ${ }^{23}$ Left unanswered are several challenging questions, including whether home office deductions are available to taxpayers who use a particular room or area in their house by (i) spending several minutes there on a daily basis or (ii) three or four hours there sporadically on a weekly basis.

Those statutes that are (or are perceived to be) inequitable, ${ }^{124}$ complex, ${ }^{125}$ or ambiguous ${ }^{126}$ tend to result in tax noncompliance. The next section of the analysis explores the implications of this phenomenon from the vantage point of home office deductions, in particular examining why

122. See, e.g., Christine v. Comm'r, T.C.M. (RIA) 2010-144 (2010) (“[Taxpayers] included in their estimate one-third of all their home expenses but provided no evidence to the Court that this is an accurate reflection of the costs of maintaining their home office.”); Rodriguez v. Comm'r, 97 T.C.M. (CCH) 1090 (2009) ("However, we do not find [the taxpayer] to be credible in allocating 40 percent of his house to his home office.").

123. Publication 587, supra note 121, at 3.

124. For example, prior to 1986 , wealthy taxpayers routinely utilized so-called Clifford trusts, eponymously named after the Helving v. Clifford (309 U.S. 331 (1940) ) case, which permitted taxpayers to fund trusts for the sole purpose of mitigating their income tax burdens. See, e.g., John A. Lynch, Jr., Shifting of Income Within the Family: Will 1986 I.R.C. Changes Bring Significant Reform?, 13 U. DAYTON L. REv. 1, 32 (1987) ("The elimination of the Clifford trust was a dramatic gesture. It removed one of the most popular, but also one of the most unfair, tax avoidance devices in the Code.").

125. For example, the daunting complexity of the partnership allocation rules led to the genesis of many pass-through entity tax shelters. See, e.g., Andrea Monroe, What's in a Name: Can the Partnership Anti-Abuse Rule Really Stop Partnership Tax Abuse?, 60 Case W. Res. L. Rev. 401, 403-04 (2010):

Thus, for taxpayers with enough sophistication or financial resources to exploit subchapter K's complexity, partnerships offer plentiful opportunities to engage in strategic behavior. Indeed, many taxpayers consider partnerships the perfect vehicle for tax shelter activity: the rules are flexible, but also technical, and the entity is less likely to be audited than its Id. transactional counterparts.

126. For example, ambiguity regarding the proper tax treatment of preferred stock dividends led taxpayers to take aggressive (and successful) reporting positions. See, e.g., Chamberlin v. Comm'r, 207 F.2d 462 (6th Cir. 1953), cert. denied, 347 U.S. 918 (1954) (utilizing a preferred stock dividend, taxpayer was able to convert ordinary income into capital gains). 
the recurrent problems associated with home office tax abuses are likely to become further exacerbated in the post-pandemic technological era.

\section{B. Tax-Avoidance Opportunities Associated with the Workplace Transformation Trend}

Before delving into possible home office tax abuses, a point requires reiteration: a healthy majority of United States taxpayers play by the rules and do not shirk their civic duties. ${ }^{127}$ Put somewhat differently, compared to other industrial nations, the United States enjoys a relatively high tax compliance rate. ${ }^{128}$

But our nation's tax compliance record is not unblemished. As previously pointed out, ${ }^{129}$ the tax gap in the United States is significant and is always under constant threat of growing. One factor involves the use of home offices. This analysis investigates the tax treatment of home office expenses with respect to those taxpayers who have an eye toward noncompliance and who have employed (or are considering employing) (1) traditional tax-avoidance methods and (2) novel tax-avoidance methods.

\section{Traditional Tax-Avoidance Methods}

For the past century, court dockets have been replete with cases involving taxpayers who have sought to use their homes as a tax shelter of sorts. ${ }^{130}$ In a number of those adjudications that the IRS brought before Code section 280A was enacted, the courts ruled against taxpayers because their home offices were used primarily for matters of personal convenience rather than business necessity, and hence the associated expenses

127. See The Tax Gap, IRS (Oct. 21, 2020), https://www.irs.gov/newsroom/ the-tax-gap [https://perma.cc/5CEB-8UJD] ("The tax gap estimates [from 2011-2013] translate to about $83.6 \%$, of taxes paid voluntarily and on time, which is in line with recent levels. The new estimate is essentially unchanged from a revised Tax Year 2008-2010 estimate of 83.8\%. After enforcement efforts are taken into account, the estimated share of taxes eventually paid is $85.8 \%$ for both periods.").

128. See Rene Chun, Why Americans Don't Cheat on Their Taxes, Atrantic (Apr. 2019), https://www.theatlantic.com/magazine/archive/2019/04/why-americansdont-cheat-on-their-taxes/583222 [https://perma.cc/H4M3-JQSN]:

But other data confirm that the U.S. is among the world's leaders when it comes to what economists call the voluntary compliance rate (VCR). In recent decades, America's VCR has consistently hovered between 81 and 84 percent. Most countries don't calculate their VCR regularly, but when they do, they lag behind the U.S. One paper that gathered what comparative data were available reported that Germany, the top European Union Id. economy, had a VCR of 68 percent.

129. See supra note 8.

130. An electronic search of the phrase home office conducted through the Research Institute of America Checkpoint library of cases on January 2, 2021, retrieved close to 1,000 cases. 
did not qualify for deductibility. ${ }^{131}$ After Congress enacted Code section 280A and a series of other legislative safeguards were instituted (e.g., limitations on the deductibility of miscellaneous itemized deductions) ${ }^{132}$ the litigation battles became more targeted, largely revolving around whether the taxpayer's home was the taxpayer's principal place of business and, in cases involving employees, if the use of a taxpayer's home was truly for the employer's convenience. ${ }^{133}$

An inventory of home office cases reveals two shared characteristics. First, taxpayers continue to deduct their everyday consumption as a form of business expense; in other words, home office utilization has opened a perceived door for taxpayers to deduct some or all of their personal expenditures, such as the cost of their utilities, refurbishments (e.g., painting and general repairs), fixtures and furniture, and rent. ${ }^{134}$ Second, even in those instances where the deductibility of these expenses might be appropriate, taxpayers lack sufficient records to substantiate their legitimacy. ${ }^{135}$

\section{Novel Tax-Avoidance Methods}

There are several reasons why twenty-first-century home usage for putative business purposes will exacerbate tax compliance issues. As amplified in further detail below, (i) there are greater opportunities for taxpayers to misclassify their personal expenses as being business related; (ii) to save employment taxes and reduce salary expenditures, there is a well-established pattern of employers misreporting taxable compensation as being nontaxable, and home office usage provides a possible platform to expand this approach; and (iii) the IRS lacks the necessary resources to monitor taxpayer compliance, particularly when home office expenses can be readily camouflaged as legitimate in nature and, furthermore, there is no third-party tax information reporting.

131. See, e.g., Salviati v. Comm'r, 36 T.C.M. (CCH) 1041 (1977) (“[W]e must hold that the claimed $\$ 342$ deduction for home office expenses is not allowable as a deductible business expense under section 162(a) but must be disallowed as a personal expense under section 262.”).

132. See I.R.C. $\S 67(\mathrm{a})$.

133. See generally Lauri K. Aldrich, Rethinking the Home Office Deduction, 49 TAx LAw. 383, 397 (1996) ("In light of the repeated unsuccessful attempts by the courts to establish a workable test for 'principal place of business,' the answer to home office deductibility is not in new interpretations, but in new legislation. In fact, it is Congress' use of the term 'principal place of business,' not the Court's interpretation of that term, that yields unequal results.").

134. See, e.g., Alka Sham v. Comm'r, 120 T.C.M. (CCH) 123 (T.C. 2020) (taxpayer attempted to deduct a number of her personal home expenses as business expenses).

135. In such instances, courts have harbored little patience regarding taxpayers' entreaties to secure tax savings. See, e.g., Weiderman v. Comm'r, 120 T.C.M. $(\mathrm{CCH}) 52$ (2020) (finding taxpayers failed to offer sufficient evidence that a supposed home office was used as part of the client's consulting business). 
(i) Misclassification Opportunities. Due to technological advancements, while a twenty-first-century home may resemble a twentieth-century home, there are several important distinctions:

- Traditional phone jacks are no longer typically installed because landlines are quickly becoming a thing of the past. ${ }^{136}$

- Increasingly, homes feature 220-volt garage electrical outlets, installed to permit quick car recharging. ${ }^{137}$

- Homeowners are utilizing geothermal mechanisms and solar panels to reduce energy costs. ${ }^{138}$

- Due to climate change, homes are increasingly equipped with power generators that provide electricity should the power grid fail. ${ }^{139}$

- So-called smart devices that can be readily activated using cell phone apps are gradually replacing yesterday's doorbells, light switches, and alarms. ${ }^{140}$

- Virtually every homeowner yearns to have good, reliable, and fast wireless fidelity (aka Wi-Fi) that enables easy access to the internet. ${ }^{141}$

136. See Hannah Louise, What to Do with Your Old Wall-Mounted Phone Jack, READER's Dig. (Apr. 4, 2019), https://www.readersdigest.ca/home-garden/homeimprovement/wall-mounted-phone-jack [https://perma.cc/3672-ZGMQ] ("What was once one of the greatest technological innovations- the landline telephoneis now quickly disappearing from homes.").

137. See Nick Kurczewski, What's the Right Electric-Car Charger for Your Home?, Consumer Reps. (Aug. 4, 2017), https://www.consumerreports.org/hybrids-evs/ whats-the-right-electric-car-charger-for-your-home [https://perma.cc/JSN4-V5UR] (explaining how many homeowners will want to equip their homes with 220-volt chargers).

138. See Irina Ivanova, Geothermal Heat Is Slowly Gaining Steam in Homes, CBS News (Mar. 1, 2018), https://www.cbsnews.com/news/geothermal-energy-isslowly-gaining-steam-in-homes [https://perma.cc/B66K-286B] (explaining how geothermal heating systems are becoming increasingly popular); John Weaver, Residential Solar Power Growing Like a "Weed", Straining Labor, PV MAg. (Oct. 28, 2019), https:/ / pv-magazine-usa.com/2019/10/28/residential-solar-power-growing-like-aweed-straining-labor [https://perma.cc/FNN9-RRMP] ("As has been the case many of the past years, the U.S. Department of Labor published that solar power installers is projected to be the fastest growing occupation from 2018-2028. . ..”).

139. See Gabrielle Hondorp, These 5 Best Standby Generators Can Help You Weather Any Storm, Popular Mechs. (Sept. 21, 2020), https:// www.popularmechanics.com/home/a34059872/best-home-standby-generators [https://perma.cc/W2SM-8Y34] (expressing that the need to have a home generator has been increased because "[m]any of us are still working from home" due to the pandemic).

140. See Alex Colon \& Angela Moscaritolo, The Best Smart Home Devices for 2021, PC MAG., https://www.pcmag.com/news/the-best-smart-home-devices-for2020 [https://perma.cc/R82C-U3TL] (last updated Apr. 26, 2021) ("Home automation is exactly what it sounds like: automating the ability to control items around the house-from window shades to pet feeders-with a simple push of a button (or a voice command).").

141. See Devin Coldewey \& James Eng, Obama Pledges to Bring Broadband Internet to Poor Households, NBC NEws (July 15, 2015), https://www.nbcnews.com/ 
There are several tax compliance implications associated with this cornucopia of changes to the modern home. In particular, a modern home's features can often serve business and personal purposes at the same time. ${ }^{142}$ A practical implication of their multitask nature is that it has become increasingly difficult to identify those expenses that relate strictly to home office use versus those that are targeted only for personal consumption.

For example, consider the plight of two psychiatrists, married to one another, who establish their home office as their principal place of business and who periodically make house calls, driving their Tesla to and from patient homes. When the taxpayers receive their monthly electric, $\mathrm{Wi}-\mathrm{Fi}$, and home security alarm bills, they will often be unable to segregate those parts of the bills that are business related from those that are personal in nature. ${ }^{143}$ And therein lies the problem: many modern home features lack clear demarcation points where business consumption ends and personal consumption begins.

(ii) Home Offices as a Possible Platform for Employer Alchemy. Both employers and employees have a financial incentive to transform the nature of income from taxable to nontaxable. The reasons for this transformation process are obvious: employers can minimize their employment tax burden, ${ }^{144}$ and employees can minimize both their payroll and income tax burdens. ${ }^{145}$ The only "loser" in arrangements of this sort is the government. In some instances, for public policy reasons, the federal government is willing to forgo revenue receipt. A case in point is how the Code handles the taxation of fringe benefits: notwithstanding the fact that such benefits represent accretions to wealth, ${ }^{146}$ for reasons of administrative convenience, the Code exempts them from tax. ${ }^{147}$ As a result, for decades employers have offered a panoply of fringe benefits to their em-

tech/internet/obama-pledges-bring-broadband-poor-communities-n392836

[https://perma.cc/HZ77-RNM8] ("'In this digital age when you can apply for a job, take a course, pay your bills, order pizza, even find a date' by using your connected phone, Obama said, 'the internet is not a luxury, it's a necessity.'”).

142. See, e.g., Danine Alati, These Are the 7 Requests Clients Will Make Post COVID19, Architectural Dig. (May 21, 2020), https://www.architecturaldigest.com/ story/these-are-the-7-features-clients-will-be-requesting-post-covid-19 [https:// perma.cc/M2S2-D5BY] ("Dedicated space for virtual meetings will also be paramount, and acoustics will become a higher priority . . . . for social, business, or educational purposes. ...'”).

143. The overall square footage of the taxpayer's home utilized for her business office versus the square footage of the rest of home is likely to be a poor metric upon which to allocate expenses.

144. See I.R.C. § 3111 (a)-(b) (2018).

145. See Deborah A. Geier, Integrating the Tax Burdens of the Federal Income and Payroll Taxes on Labor Income, 22 VA. TAx REv. 1, 19 (2002) (explaining the interplay between the income tax and payroll taxes).

146. See I.R.C. § 61(a) (2017).

147. See Wendy Gerzog Shaller, The New Fringe Benefit Legislation: A Codification of Historical Inequities, 34 CATH. U. L. Rev. 425, 426 (1985) ("Admittedly, both working condition fringe benefits and de minimis fringe benefits may be justified on 
ployees, and this trend is steadily expanding. ${ }^{148}$ Indeed, a whole host of technology-based (and other) companies now regularly offer a laundry list of benefits (e.g., gourmet meals) in lieu of taxable compensation to their employees; and, to date, the implementation of this strategy has gone unchallenged by the IRS. ${ }^{149}$

In the aftermath of the pandemic and due to technological advancements, we can anticipate that many employers will likely decide, for their convenience, to have employees work at home. Due to the fact that the Code categorizes employees' out-of-pocket business expenses as miscellaneous itemized deductions and, as such, not deductible, ${ }^{150}$ employers and employees are apt to adopt strategies to circumvent this limitation. Consider one such strategy. Utilizing a so-called accountable plan, ${ }^{151}$ employers will reimburse their employees for any of their home expenses that have even a modicum of business relatedness. In return for reimbursing their employees, cagey employers will quietly demand that their employees' salaries be pruned a bit or not raised as quickly. Employers are apt to grant employees a fair amount of latitude in what they permit employees to submit for reimbursement. Why? Because for every dollar that the employers cover, they save on employment taxes. And employees are apt to go along with this plan. Why? Because in the employees' hands, such reimbursements will not be subject to either income or payroll taxes.

An example helps illustrate the dynamics of this proposed subterfuge strategy. Suppose a company pays employee Bea an annual salary of $\$ 100,000$. Suppose further that the company asks Bea to work at home and agrees to reimburse Bea for her business-related home expenses. Bea

the ground of administrative convenience; they add to the simplification of the tax laws and do not produce inequitable results.").

148. See Jay A. Soled \& Kathleen DeLaney Thomas, Revisiting the Taxation of Fringe Benefits, 91 WASH. L. REv. 761, 761 (2016) ("Technological advances and workforce globalization are important contributory factors to the popularity of what were, until the turn of this century, previously unknown fringe benefits.").

149. See, e.g., Austin L. Lomax, Note, Five-Star Exclusion: Modern Silicon Valley Companies Are Pushing the Limits of Section 119 by Providing Tax-Free Meals to Employees, 71 Wash. \& LeE L. Rev. 2077 (2014) (describing the nonreporting practices of both employers and employees with regard to the many third-party-provided fringe benefits of work); Michael Lundin \& Claudia Cowan, IRS Considers Taxing Work Perks Like Food, Gym Memberships, Fox News, https://www.foxnews.com/politics/irsconsiders-taxing-work-perks-like-food-gym-memberships [https://perma.cc/77XRH597] (last updated Dec. 20, 2015) ("The IRS reportedly is looking at these perks and seeing if these companies need to start paying up for the free stuff they offer employees."); Thuy Nguyen, Note, Employee Perks in Silicon Valley: Technology Companies Lead the "Arms Race" As Corporate Law Trails in Representing Shareholder Interests, 12 Hastings Bus. L.J. 51, 51 (2015) ("The practice of providing 'in-kind' perks to employees that go beyond the traditional benefits of health care coverage and retirement plans has spread throughout Silicon Valley technology companies at a rapid pace within the last decade. At the same time, the value of these perks has increased exponentially." (footnote omitted)).

150. I.R.C. $\S 67(\mathrm{~g})(2017)$.

151. Id. §62(c) (2020); Treas. Reg. § 1.62-2(c)(2)(i) (1989). 
uses one-fifth of her home as her business office and incurs the following annual expenses: $\$ 20,000$ in utilities, $\$ 5,000$ in high-speed internet service, $\$ 6,000$ in security expenditures, $\$ 5,000$ in local property taxes, and $\$ 15,000$ in landscaping and maintenance costs. Bea submits a request for $\$ 19,000$ of reimbursements, ${ }^{152}$ which include, despite their personal use, all of Bea's Wi-Fi and security expenses under the theory that, but for her home office, she would not have secured the high-speed internet service or security system. Bea's employer honors this reimbursement request; and because it is being so generous with its home office reimbursements, her employer decides not to raise Bea's salary the following year. Given the IRS's likely difficulties of identifying and then challenging arrangements of the sort just described, ${ }^{153}$ anticipate that these sorts of reimbursement practices will become increasingly widespread.

(iii) The IRS's Inability to Monitor Home Office Tax Issues. By way of background, for the last several decades, the IRS has become a beleaguered agency. It has seen its funding drastically cut and its workforce decimated. ${ }^{154}$ Furthermore, Congress has failed to grant the IRS up-todate analytic tools to monitor taxpayer compliance. ${ }^{155}$ In the meantime, the number of tax returns that the IRS must process annually has grown by leaps and bounds. ${ }^{156}$ The by-product of these circumstances is a tax return audit rate hovering at historic lows, ${ }^{157}$ granting tacit license to lessthan-civic-minded taxpayers to skimp on paying their rightfully owed taxes.

The specific challenges associated with a depleted oversight agency trying to examine the legitimacy of home office expenses are not hard to

152. That is, $\$ 4,000$ for utilities, $\$ 5,000$ in high-speed internet service, $\$ 6,000$ in security expenditures, $\$ 1,000$ in local property taxes, and $\$ 3,000$ in landscaping and maintenance costs.

153. Employee reimbursements of the sort described will not be reported on the employee's individual income tax return and the submission to the employer for reimbursement, on its face, will have the cloak of legitimacy.

154. See, e.g., Paul Kiel \& Jesse Eisinger, How the IRS Was Gutted, ProPublica (Dec. 11, 2018), https://www.propublica.org/article/how-the-irs-was-gutted [https://perma.cc/9U32-UMGC] (describing the underfunding of the IRS).

155. See Jesse Eisinger \& Paul Kiel, Why the Rich Don't Get Audited, N.Y. Times (May 3, 2019), https://www.nytimes.com/2019/05/03/sunday-review/tax-richirs.html [https://perma.cc/LJ59-CB9V] ("Today, the wealthy and corporations have the I.R.S. outgunned. The ultra-affluent-with the help of legions of tax professionals - make domestic income disappear overseas or hide it in a pyramid of partnerships. It's like trying to take on a modern army while armed with spears and clubs.").

156. For a historical view of the annual filing season statistics by year, see Filing Season Statistics by Year, IRS (Dec. 1, 2020), https://www.irs.gov/newsroom/filing-season-statistics-by-year [https://perma.cc/4U67-RN3F].

157. See Aimee Picchi, Your Chance of Getting Audited by the IRS Is Lower Than Ever, CBS News (Jan. 7, 2020), https://www.cbsnews.com/news/irs-audit-rate-lowest-in-at-least-a-decade [https://perma.cc/NYA3-DRUR] ("Taxpayers are half as likely to be audited by the Internal Revenue Service as they were a decade ago following a sharp reduction in staff over the past several years."). 
ascertain. By their nature, home office audits are apt to be labor-intensive. ${ }^{158}$ IRS auditors likely have to make a site visit, which given the personal nature of the home, is, in all likelihood, bound to be perceived as overly intrusive. This can possibly stymie an auditor's ability to conduct a thorough investigation. And as home office use expands, anticipate that this beleaguered agency will be further stretched in its ability to fulfill its oversight mission.

\section{Reform Measures: Existing and Proposed}

In light of the ubiquity of home office deductions and what will likely be their increasing prevalence, they warrant special scrutiny, particularly because of their mixed-use nature. Section A investigates existing Code safeguards to curb taxpayer abuse and why, in today's workplace structure, they may fall short of achieving their objectives. Section B offers reform measures that Congress, the Treasury Department, and the IRS should consider instituting in order to enhance taxpayer compliance.

\section{A. Existing Safeguards to Curb Potential Taxpayer Abuse}

When it comes to mixed-use assets and tax avoidance, Congress, the Treasury Department, and the IRS have each exhibited vigilance. Insofar as home office expenses are concerned, consider a number of measures currently in place that attempt to halt tax abuses.

For starters, in recognition that home office deduction abuses were becoming increasingly commonplace and notwithstanding the general safeguards of Code section 162, Congress enacted Code section 280A, specifically designed to curb these practices. ${ }^{159}$ And since its enactment, this

158. See generally, Paul Kiel, IRS: Sorry, but It's Just Easier and Cheaper to Audit the Poor, ProPublica (Oct. 2, 2019), https://www.propublica.org/article/irs-sorry-butits-just-easier-and-cheaper-to-audit-the-poor [https://perma.cc/N9UP-DE3N] ("On the other hand, auditing the rich is hard. It takes senior auditors hours upon hours to complete an exam. What's more, the letter says, 'the rate of attrition is significantly higher among these more experienced examiners.' As a result, the budget cuts have hit this part of the IRS particularly hard.").

159. The legislative origins of Code section 280A are concisely spelled out in Drucker v. Commissioner.

Congress enacted section $280 \mathrm{~A}$ to provide "definitive rules relating to deductions for expenses attributable to the business use of homes." Prior to the enactment of section 280A, we employed an "appropriate and helpful" standard in determining whether a home office deduction was proper. Congress, in specifically rejecting that standard, opted for a less "subjective determination" and intended to set out clear rules in order to alleviate administrative burdens which it believed were inherent in such a standard. Congressional dissatisfaction with the "appropriate and helpful" standard, however, was not limited to the perceived inherent administrative problems; Congress also felt that such a standard would result in treating nondeductible personal living expenses as ordinary and necessary business expenses.

Drucker v. Comm'r, 79 T.C. 605, 611-12 (1982) (footnote omitted) (citations omitted). 
statutory reform measure appears to have proven somewhat efficacious, as evidenced by its routine use by the IRS to commence cases against putatively errant taxpayers. ${ }^{160}$

Another compelling reason that home office deductions have not proven to be a tax shelter bonanza is that Congress has cast a vigilant eye toward their use by employees. As previously pointed out, for employees to take this deduction, it must be for the "convenience of [their] employer[s]." 161 And, even in those instances when employees meet this requirement, the Code imposes another limitation: it categorizes such employee expenditures as "miscellaneous itemized deductions," 162 which, for several decades, have only been deductible if they exceed two percent of an employee's adjusted gross income. ${ }^{163}$ Furthermore, from 2018 through 2025, the deductibility of such expenses has been suspended. ${ }^{164}$ These limitations, therefore, foreclose this area of potential abuse, except in the situation mentioned above related to employer reimbursements of employees' home office expenses.

Consider, too, that in its most recent legislative foray embodied in the Tax Cuts and Jobs Act of 2017, ${ }^{165}$ Congress raised the standard deduction amount ${ }^{166}$ and capped the deductibility of state and local taxes. ${ }^{167}$ The practical implication of these two adjustments is that even after the suspension on the deductibility of miscellaneous itemized expenses ends in 2026, the vast majority of employee taxpayers will continue to use the standard deduction rather than itemize their deductions, including those expenses that pertain to their home offices.

Finally, when it comes to home office expenses, taxpayers cannot willy-nilly claim their availability. Instead, taxpayers have the initial burden of proof to substantiate that they incurred such expenses. ${ }^{168}$ This is a burden of proof that taxpayers often cannot meet; and if they cannot meet this burden of proof, they must forfeit the deductibility of their home office expenses, even if those expenses are legitimate. ${ }^{169}$

Notwithstanding the fact that the safeguards enumerated above have operated effectively, the country must brace itself for the coming on-

160. See Robert W. Wood, Home Office, Vacation Home, and Home Rental Deductions, 547-3d Tax Mgmt. Portfolio (BNA), at bibliog. \& references (2020).

161. I.R.C. $\S 280 \mathrm{~A}(\mathrm{c})(1)(1999)$.

162. Id. $\S 67(\mathrm{~b})$.

163. Id. $\$ 67(\mathrm{a})$.

164. See id. $\S 67(\mathrm{~g})$.

165. Pub. L. No. 115-97, 131 Stat. 2087 (2017).

166. See id. $\$ 11021(\mathrm{a})$.

167. See id. \$11042(a).

168. See I.R.C. $\S 7491(\mathrm{a})$.

169. If taxpayers lack the necessary records to substantiate their expenses, courts routinely deny taxpayers' deductions. See, e.g., Cartwright v. Comm'r, T.C. Memo 2015-212 (2015) (noting a married couple failed to meet their evidentiary burden of proof to demonstrate that their motor home was utilized for business rather than for personal purposes). 
slaught of taxpayers seeking either to deduct their home office expenses or to exempt their reimbursement of them from being considered taxable income. ${ }^{170}$ Furthermore, on numerous and repeated occasions, the country's employers have utilized aggressive tactics to minimize their own and their employees' tax burdens ${ }^{171}$ — and thus there is every reason to suspect that they will do the same when it comes to reimbursing employees for their home expenses in a manner that stretches beyond the bounds of permissibility.

Members of Congress, the Treasury Department, and the IRS accordingly should prepare themselves for concerted taxpayers' efforts to reduce their tax burdens by taking aggressive reporting positions regarding the use of their home offices. If elected officials and public servants undertake proper precautions, the fate and integrity of the country's income tax base will remain intact.

\section{B. Suggested Reform Measures to Curb Potential Taxpayer Abuse}

Curbing potential tax abuse is never an easy undertaking. If done haphazardly, it will constitute a temporary fix that functions merely as a makeshift Band-Aid, failing to address long-term and systemic problems. Instead, if properly handled, reform should be systematic and comprehensive, anticipating any and all avenues of potential tax abuse. Before delving into specific recommendations, an acknowledgement must be made that unlike other tax shelters (e.g., those techniques that artificially manufacture tax losses), ${ }^{172}$ home office expenses can be and often are legitimate. Consider a self-employed landscaper, Taxpayer A, who wants to minimize overhead expenses. Rather than rent commercial office space or a truck parking area, Taxpayer A uses the basement of his two-story house entirely to operate their business, which includes furniture and fixtures, a tool supply chest, and a computer network; in addition, Taxpayer

170. A quick glance at the avalanche of articles posted on mainstream media sites affirms that taxpayers are being strongly encouraged to view their homes as potential tax shelters. See, e.g., Shehan Chandrasekera, How People Working from Home Can Claim a Home Office Tax Deduction, Forbes (Mar. 18, 2020), https:// www.forbes.com/sites/shehanchandrasekera/2020/03/18/how-coinbasegemini-blockstack-employees-working-from-home-can-claim-tax-deductions / [https://perma.cc/VK2E-GXBZ] (extolling the virtues of home office deductions); Tanza Loudenback, There's a Tax Deduction for People Working from Home, but It Won't Apply to Most Remote Workers During the Pandemic, Bus. Insider (Feb. 1, 2021), https://www.businessinsider.com/personal-finance/claiming-home-officetax-deduction-work-from-home-2020-4 [https://perma.cc/Z3CA-ZA8B] (explaining how the deduction operates).

171. See I.R.C. $\S 3111$ (a)-(b) (2018).

172. See I.R.C. $\$ 6662$ (d) (2) (C) (ii) (2020) (“[T] he term 'tax shelter' means(I) a partnership or other entity, (II) any investment plan or arrangement, or (III) any other plan or arrangement, if a significant purpose of such partnership, entity, plan, or arrangement is the avoidance or evasion of Federal income tax."); see also Karen C. Burke \& Grayson M.P. McCouch, Cobra Strikes Back: Anatomy of a Tax Shelter, 62 TAx LAw. 59 (2008) (describing tax shelter techniques that manufactured artificial tax losses). 
A uses his driveway to park his mowing machinery and trucks. Accordingly, Taxpayer A should be able to deduct one-third of his overall housing expenses, such as property taxes and utility costs. This dollar figure would likely correspond to those expenses the landscaper would have incurred had the landscaper rented office space or purchased an office complex and depreciated its cost.

But the foregoing situation must be juxtaposed with one in which home office deductions are not legitimate. In the prior example, suppose the same landscaper operates a commercial nursey ten miles from his home. Periodically, the landscaper brings some administrative paperwork to his home that he, on average, completes in thirty to forty minutes from a desk located in his basement. In contravention of the Code, the landscaper claims that one-third of his home office expenses are deductible. Clearly, the IRS must be in a position to identify this dereliction and seek compliance.

Thus, this is the challenge: how can the nation strike the right balance between allowing those legitimate home office expenses that should be able to offset gross income (under Code section 162) and disallowing those that should not be deductible (under Code section 262) because elements of personal consumption predominate? In responding to this question, the following five recommendations warrant consideration.

\section{Reform the Penalty Structure for Taxpayers}

Admittedly, there is a plethora of cases stretching from every decade that the income tax has been in existence that illustrate a long history of less-than-civic-minded taxpayers mischaracterizing their personal expenses as business in nature and attempting to deduct them. ${ }^{173}$ To curtail this practice, Congress has instituted a comprehensive penalty system that ap-

173. In every decade since the modern income tax came into being, cases of this nature have been adjudicated. See, e.g., Wakefield v. Comm'r, 17 B.T.A. 1335 (1929) (holding taxpayer could not prove so-called business expenses were not truly personal in nature); Markham v. Comm'r, 39 B.T.A. 465 (1939) (holding payment made to obtain evidence regarding an extortion letter threatening harm to the taxpayer's children was made for personal rather than business reasons); Comm'r v. Flowers, 326 U.S. 465 (1946) (travel expenses held to be nondeductible personal rather than business expenses); Comm'r v. Doak, 234 F.2d 704, 709 (4th Cir. 1956) (" $[\mathrm{T}]$ he items here involved may be viewed, on the one hand, as business expenses, on the other hand, as personal. We think their essential nature, their inherent and dominant attributes characterize them as personal with a tinge of business and not as business with a personal tinge."); Hitchcock v. United States, 63-2 U.S.T.C. II 9756 (E.D. Wash. 1963) (business deduction denied for a wedding gift); Nicholls, N., Buse Co. v. Comm'r, 56 T.C. 1225 (1971) (yacht used for personal pleasure taxpayers mischaracterized as a business expense); Daly v. Comm'r, 631 F.2d 351 (4th Cir. 1980) (taxpayer's travel expenses were personal rather than business in nature); In re Williams, No. 92-61503, 1995 B.R. LEXIS 2171 (Bankr. N.D. Ind. May 5, 1995) (ruling that taxpayer's expenses were not business in nature but instead were personal expenses); Wilbert v. Comm'r, 553 F.3d 544 (7th Cir. 2009) (taxpayer travel expenses away from home were personal rather than business in nature); Dargie v. United States, 742 F.3d 243 (6th Cir. 2014) (tax- 
plies in the following fashion: the more egregious the taxpayer derelictions, the higher the penalty imposed; ${ }^{174}$ furthermore, when taxpayers fail to report ten percent or more of their income, an automatic penalty is imposed. ${ }^{175}$

In like fashion, Congress should consider reforming the penalty structure in the case of illegitimate home office expense deductions. The law should apply an automatic negligence penalty in those instances when a taxpayer's disallowed office expenses exceed a certain monetary threshold (say, $\$ 10,000) .{ }^{176}$ For example, suppose a taxpayer has a home office and deducts $\$ 20,000$ in depreciation expenses, $\$ 8,000$ in property taxes, $\$ 7,000$ in utility costs, $\$ 6,000$ in home security fees, and $\$ 5,000$ in Wi-Fi charges, for a total of $\$ 46,000$. Upon audit, suppose further that an IRS examiner permits only $\$ 21,000$ of such expenses as legitimate home office deductions and designates the other $\$ 25,000$ as a nondeductible personal expense. In a case such as this, a twenty percent accuracy-related penalty would automatically apply to the tax burden associated with the additional $\$ 25,000$ of reportable income.

\section{Address Potential Employer-Employee Collusion}

Insofar as employers are concerned, in terms of minimizing their need for commercial real estate, they are quickly learning that their employees' home office use can save them enormous out-of-pocket expenses. What they are also apt to learn is that employee home office use offers a secondary financial respite in the form of bountiful employment tax savings. ${ }^{177}$ When employers grasp this concept, it is safe to anticipate that they will aggressively transform their business models and establish employment relations that, at least on paper, claim that for their convenience their employees are working from home.

Consider a simple example that illustrates this point. Suppose a company has 100 employees and pays each one $\$ 50,000$ in annual salary. On this overall $\$ 5$ million company payroll (i.e., $100 \times \$ 50,000$ ), under current law the associated payroll tax burden would be $\$ 382,500$ (i.e., $100 \mathrm{x}$ $\$ 50,000 \times 7.65 \%) .{ }^{178}$ Suppose the company instead had its employees work from home, picking up $\$ 10,000$ of their putative home office ex-

payer's payment of medical school tuition was a personal rather than business expense).

174. See also I.R.C. $\$ 6662$ (a) (imposing a twenty percent penalty when a taxpayer acts negligently); see also I.R.C. \$6662(i) (imposing a forty percent penalty for engaging in nondisclosed transactions that lack economic substance); I.R.C. $\S 6663$ (a) (imposing a seventy-five percent penalty when a taxpayer acts fraudulently).

175. See I.R.C. $\$ 6662(d)$ (2020) (imposing a ten percent strict liability penalty when taxpayers substantially underreport their incomes).

176. A penalty could also be imposed if a certain percentage of home office expenses are disallowed.

177. See supra note 144 and accompanying text.

178. See I.R.C. § 3111 (a)-(b) (2018). 
penses (e.g., utilities, Wi-Fi, and home security costs) while paying them annual salaries of $\$ 40,000$. The company's payroll would decrease by $\$ 1$ million (i.e., $100 \times \$ 10,000$ ), yielding $\$ 76,500$ in payroll tax savings (i.e., $\$ 1$ million $\mathrm{x} 7.65 \%) .{ }^{179}$ Indeed, under the circumstances, assuming the company could reduce the salary it paid its employees by a corresponding dollar amount, the company would be wise to instruct its employees to aggressively search for home office expenses. Employees would be willing colluders in this sheltering enterprise if the items for which they were reimbursed supplemented their personal living needs. Said another way, employees would be ecstatic if they were able to transform otherwise taxable income into a bonanza of in-kind tax-free income.

As employers gradually transform their business office models, Congress should take action. The first thing that our nation's legislative body should do is amend Code section $280 \mathrm{~A}(\mathrm{a})(1)(\mathrm{C})$ to ensure that an employee's home office is truly for the employer's convenience. This Code section currently reads, in part, as follows:

In the case of an employee, the preceding sentence shall apply only if the exclusive use referred to in the preceding sentence is for the convenience of his employer. ${ }^{180}$

A clause should be added to the end of the foregoing sentence so that the section would read as follows:

In the case of an employee, the preceding sentence shall apply only if the exclusive use referred to in the preceding sentence is for the convenience of his employer and the employee has no office space available at the employer's business location to perform his responsibilities.

Adding this clause would introduce another deduction criterion and significantly limit wayward employers from engaging in possible tax shenanigans. An employer who supplied any office space to an employee would be precluded from using a disingenuous reimbursement scheme to dodge its own and its employees' tax obligations.

Second, Congress should seek to ensure the legitimacy of taxpayers' home office expenses. To achieve this objective, it should signal its intolerance of potential collusive opportunities between employers and employees. More specifically, in those situations in which the IRS recharacterizes home office reimbursement expenses as taxable remuneration to an employee, the Code should deny "ordinary and necessary" salary deductions sought by the employer. ${ }^{181}$

To illustrate the application of this proposed rule, suppose ABC Corporation has 100 employees and it reimburses $\$ 1$ million of purported

179. See id.

180. Id. $\S 280 \mathrm{~A}(\mathrm{a})(1)(\mathrm{C})(1999)$.

181. Id. $\$ 162(\mathrm{a})(1)$. 
employee home office expenses. Upon audit, suppose further that the IRS disallows $\$ 400,000$ of these reimbursement expenses, deeming such expenditures instead as in-kind compensation to ABC Corporation's employees. As such, ABC Corporation would endure little meaningful downside risk from engaging in such collusion with its employees; one way or another, reimbursement of the home office expenses would be deductible to it either as a (i) legitimate cost of doing business (i.e., office space expenditure) ${ }^{182}$ or (ii) salary payment. ${ }^{183}$ Admittedly, ABC Corporation would bear some additional employment tax burden if its reimbursements were deemed to constitute disguised salary payments; ${ }^{184}$ however, as a practical matter, due to the general three-year statute of limitations, ${ }^{185}$ it would likely be difficult (perhaps impossible?) for the IRS to pursue all of ABC Corporation's employees for their failure to report these in-kind salary payments. In light of this, employers such as ABC Corporation should suffer more meaningful consequences stemming from their aggressive home office reporting stances: Congress should preclude them from deducting these mischaracterized amounts as remuneration expenses. ${ }^{186}$ Thus, in the example posited, ABC Corporation would have to bear the concomitant income tax associated with the $\$ 400,000$ disallowed deduction.

\section{Promulgate Regulations to Clarify the Word Regular}

The Treasury Department should be prodded to promulgate regulations that add clarity to this area of the law. For years, taxpayers have struggled to understand and apply the word regular as used in the statute, unaided by the legislative history, which offers scant additional amplification or guidance. ${ }^{187}$ The Treasury Department should take this opportunity to define the word regular in a manner most likely to halt possible taxpayer abuse. One suggestion is for the Treasury Department to turn directly to Merriam-Webster's Dictionary, which defines the word regular to mean "recurring . . . at fixed, uniform, or normal intervals[,]"188 and insert this definition directly into the regulations. ${ }^{189}$ Refining the existing Treasury regulations that clarified this standard would better arm the IRS to attack frivolous taxpayer positions.

182. See id. $\S 162(\mathrm{a})(3)$.

183. See id. $\S 162(\mathrm{a})(1)$.

184. See supra note 144.

185. I.R.C. $§ 6501(\mathrm{a})$.

186. This stance would not be unique. In plenty of other places in the Internal Revenue Code, Congress selectively precludes deductions (e.g., I.R.C. $\S 274(\mathrm{a})$ ) and disallows or curtails losses (e.g., I.R.C. $§ 165(\mathrm{c}),(\mathrm{d})$ ).

187. See supra note 110.

188. Regular, Merriam-Webster's Dictionary (2021).

189. The current Treasury regulations simply make the following declaration: "The determination whether a taxpayer has used a portion of a dwelling unit for a particular purpose on a regular basis must be made in light of all the facts and circumstances." Prop. Reg. § 1.280A-2(h). 


\section{Craft a Questionnaire as a Guide for Taxpayers}

Finally, when it comes to the IRS and the agency's need to scrutinize taxpayers' home office expenses, it should develop a standard questionnaire to be used for field examinations and share it with the general public. If taxpayers know in advance the nature of deductible expenses that are permissible and the kind of substantiation documentation necessary to produce on audit, they would be in a far better position to know the permissible parameters associated with home office deductions.

\section{Increase IRS Funding}

Whether the IRS can truly oversee the legitimacy of home office expenses, however, rests upon one further consideration-namely, the adequacy of the agency's funding. ${ }^{190}$ Indeed, absent suitable funding, this proposed oversight exercise will ultimately prove to be an exercise in futility.

\section{Conclusion}

There is an old adage that, over time, things generally come full circle. This is certainly true of the work-home relationship. In yesteryear, in rural America, many taxpayers worked in or in very close proximity to their homes. The Industrial Revolution ended this practice. As the nation transitioned from farming and ranching to manufacturing and services, taxpayers were forced to leave their homes and commute to and from work. Now, due to technological advances and the pandemic, taxpayers are returning in droves to work from their homes again.

While this workplace transformation has many important implications, one of the most salient is in the realm of tax compliance. Left unchecked, taxpayers and their employers may use tax-minimization techniques that are fundamentally at odds with basic Code precepts. This may be accomplished through the use of traditional and novel tax-avoidance stratagems. In terms of potential lost revenue, the associated price tag for the government's failure to address this emerging issue is likely to be steep.

But this is not a problem that lacks a solution. There are many viable reform approaches that should be implemented. From a legislative vantage point, Congress should consider instituting additional statutory safeguards; the Treasury Department should promulgate regulatory guidance that demystifies home office compliance; and, finally, the IRS should step up its enforcement efforts and send a signal that it intends to police this critical area of the law. If these various remedial measures are instituted, the deductibility of home office expenses will no longer be a cause of concern; instead, tax compliance associated with the incurrence of such expenses will be assured.

190. See Kiel \& Eisinger, supra note 154. 
Soled: Workplace Transformation And Its Tax Compliance Implications

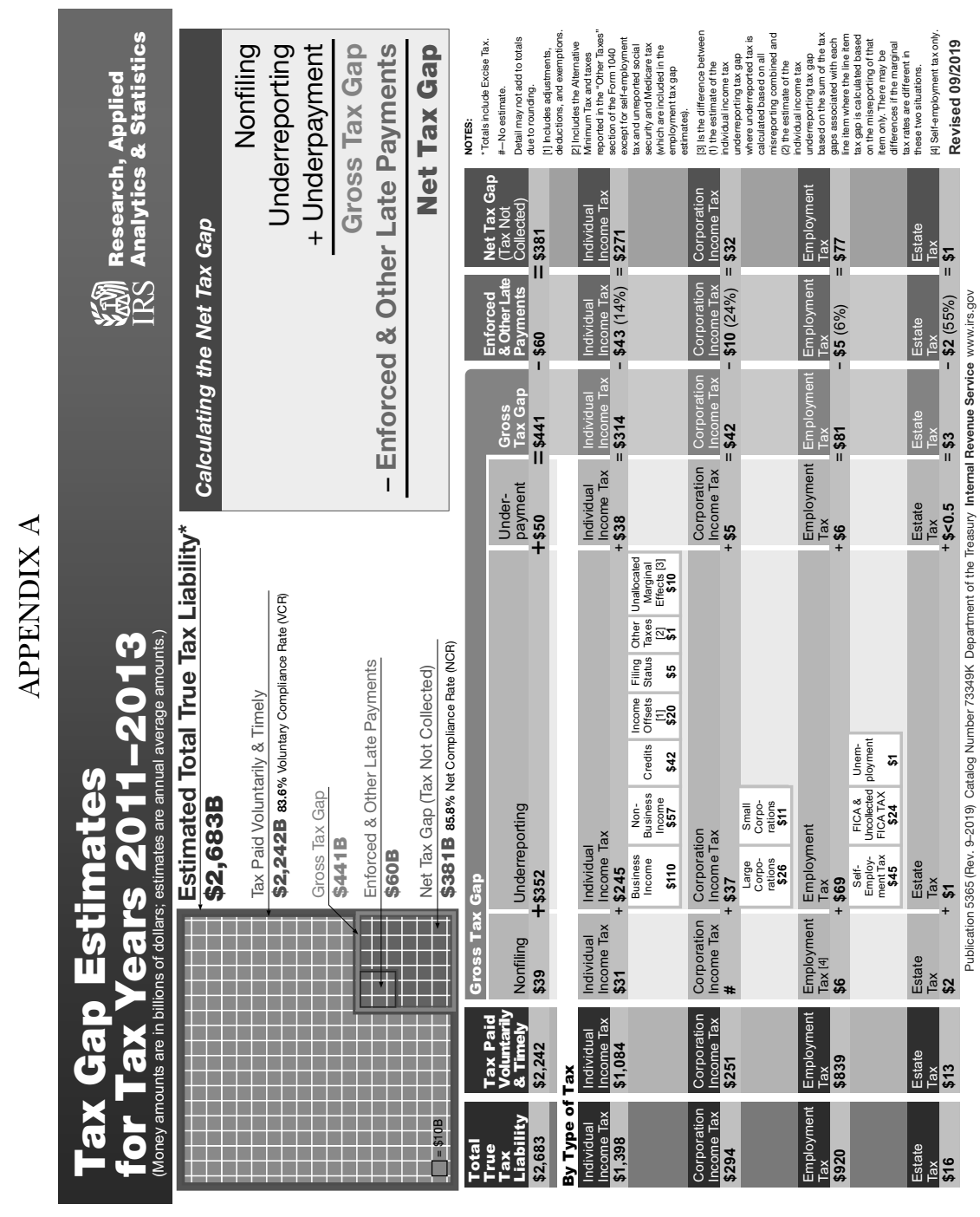


Villanova Law Review, Vol. 66, Iss. 3 [2021], Art. 3

614

Villanova Law Review

[Vol. 66: p. 575 